\title{
River response to an active fold-and-thrust belt in a convergent margin setting, North Island, New Zealand
}

\author{
Merri Lisa Formento-Trigilio $^{\mathrm{a}, *}$, Douglas W. Burbank ${ }^{\mathrm{b}, 1}$, Andrew Nicol ${ }^{\mathrm{c}, 2}$, \\ James Shulmeister ${ }^{\mathrm{d}, 3}$, Uwe Rieser ${ }^{\mathrm{e}, 4}$ \\ ${ }^{a}$ Department of Geosciences, The Pennsylvania State University, University Park, PA 16802, USA \\ ${ }^{\mathrm{b}}$ Institute for Crustal Studies, University of California, Santa Barbara, CA 93106, USA \\ ${ }^{\mathrm{c}}$ Institute of Geological and Nuclear Sciences, P.O. Box 30 368, Lower Hutt, New Zealand \\ ${ }^{\mathrm{d}}$ Department of Geology, University of Canterbury, Private Bag 4800, Christchurch, New Zealand \\ ${ }^{\mathrm{e}}$ Luminescence Dating Laboratory, School of Earth Sciences, Victoria University of Wellington, P.O. Box 600, Wellington, New Zealand
}

\begin{abstract}
High-resolution digital elevation data (TOPSAR 10-m grid) are used to reconstruct Late Quaternary growth histories of subtle folding in the Wairarapa fold-and-thrust belt, North Island, New Zealand. Outcrop data of deformed latest Miocene and younger strata are combined with observations of warped and faulted late Quaternary terrace surfaces to unravel the geomorphic and structural history of the Huangarua River valley. Optically stimulated luminescence (OSL) dating of loess that accumulated on these strath terraces and paleosol stratigraphy allow temporal correlation among the terraces and with glacial climate cycles since the Last Interglaciation. These data indicate that five intervals of strath cutting occurred, at $\sim 125,60-70, \sim 30, \sim 15$, and $<10 \mathrm{ka}$. Strath beveling is largely independent of local folding or regional base-level change. We hypothesize that straths are cut when an increase in sediment supply, during cool climatic periods, brings river sediment load and river transport capacity into balance. In the Wairarapa, strath-cutting events appear to occur near the end of cool climatic cycles.This study shows that the identification of subtle departures from regional topographic trends becomes practical when a high-resolution DEM is available. After subtraction of an average valley gradient from the digital topography, the residual topography on the terrace treads reveals cross-valley and longitudinal tilting. Although rates of folding are slow and the magnitude of deformation is commonly limited to less than a few tens of meters, these topographic anomalies define fold axes that coincide with subsurface structures. When combined with time control, these anomalies serve to define the patterns and rates of fold growth over the past 125 kyears.
\end{abstract}

(C) 2002 Elsevier Science B.V. All rights reserved.

Keywords: Geomorphology; Fold-and-thrust belt; Strath terrace; New Zealand

\footnotetext{
* Corresponding author. Fax: +1-814-863-8724.

E-mail addresses: mlft@geosc.psu.edu (M.L. Formento-Trigilio), Burbank@crustal.ucsb.edu (D.W. Burbank), A.Nicol@gnes.cri.nz (A. Nicol), j.Shulmeister@geol.canterbury.ac.nz (J. Shulmeister), Uwe.Rieser@vuw.ac.nz (U. Rieser).

${ }^{1}$ Fax: + 1-805-893-8649.

${ }^{2}$ Fax: + 64-4-570-4603.

${ }^{3}$ Fax: +64-3-364-2769.

${ }^{4}$ Fax: $+64-4-463-5186$
} 


\section{Introduction}

Impressive suites of fluvial terraces that step down toward the modern channel characterize many rivers in New Zealand. Fluvial terraces can be used to record a river's response to differential uplift along or across faults and folds (Keller et al., 1982; Burnett and Schumm, 1983; Rockwell et al., 1984; Pazzaglia and Gardner, 1993; Personius et al., 1993; Merritts et al., 1994; Molnar et al., 1994; Nicol et al., 1994;
Personius, 1995; Burbank et al., 1996; Lavé and Avouac, 2000). In the last 20 years, the role of fluvial terraces in neotectonic studies has expanded from a passive geomorphic marker that records fault displacement in paleoseismic studies to strain markers used to infer underlying fold geometries in the substrate (Molnar et al., 1994; Lavé and Avouac, 2000). The height of terrace surfaces above the modern river profile is commonly used to calculate incision rates that are then used as a proxy for rock-uplift rates

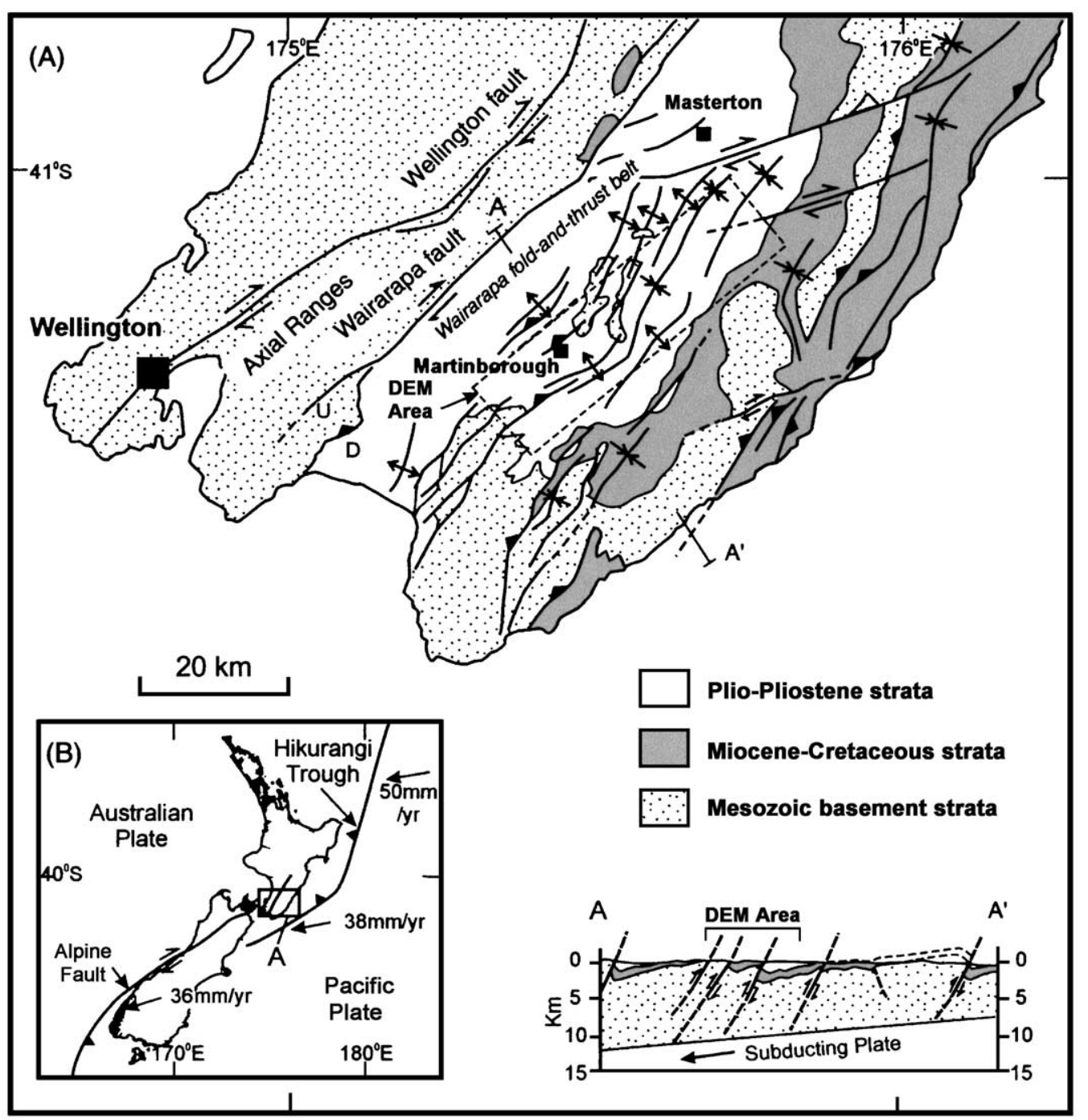

Fig. 1. (A) Regional structural setting of the southern North Island, New Zealand. A dashed box outlines the area encompassed by the TOPSAR DEM data. Cross section $\mathrm{A}-\mathrm{A}^{\prime}$ is pictured below (modified after Nicol et al., in preparation). (B) Inset showing plate tectonic convergence rates. 
either assuming a time-invariant river profile (Molnar et al., 1994) or using a reconstructed river profile (Lavé and Avouac, 2000). If these assumptions are valid and if terraces are preserved across the fold hinge, along drainages oriented transverse to geologic structure, then predictive fold models, such as faultbend-fold or fault propagation theories (Suppe and Medwedeff, 1990; Suppe, 1992), can be combined with geometric relationships to constrain fault slip on fold ramps (Lavé and Avouac, 2000).

In the Wairarapa fold-and-thrust belt, North Island, New Zealand, terraces are not preserved across folds; however, we define spatial and temporal patterns of fold growth using digital elevation data and detailed field mapping of deformed late Quaternary terraces that overlie Latest Miocene and younger sedimentary rocks. A digital elevation model (DEM) based on TOPSAR (synthetic aperture radar) data spanning the Wairarapa folds was acquired from NASA-JPL. The data span a $10 \times 50 \mathrm{~km}$ area (Fig. 1) and provide a highly detailed topographic database with which to calibrate fluvial terrace deformation at horizontal and vertical resolutions of 10 and $1 \mathrm{~m}$, respectively (Fig. 2). Optically stimulated luminescence (OSL) dating of loess that overlies the fluvial terraces serves to define absolute rates of tilting and fold growth. These OSL dates are interpreted in the context of a regional tephrochronology and paleosol stratigraphy. The welldefined regional loess and paleosol sequence reflects environmental changes during glacial and interglacial cycles. This regional record, when combined with local soil stratigraphy from over a dozen trenches and

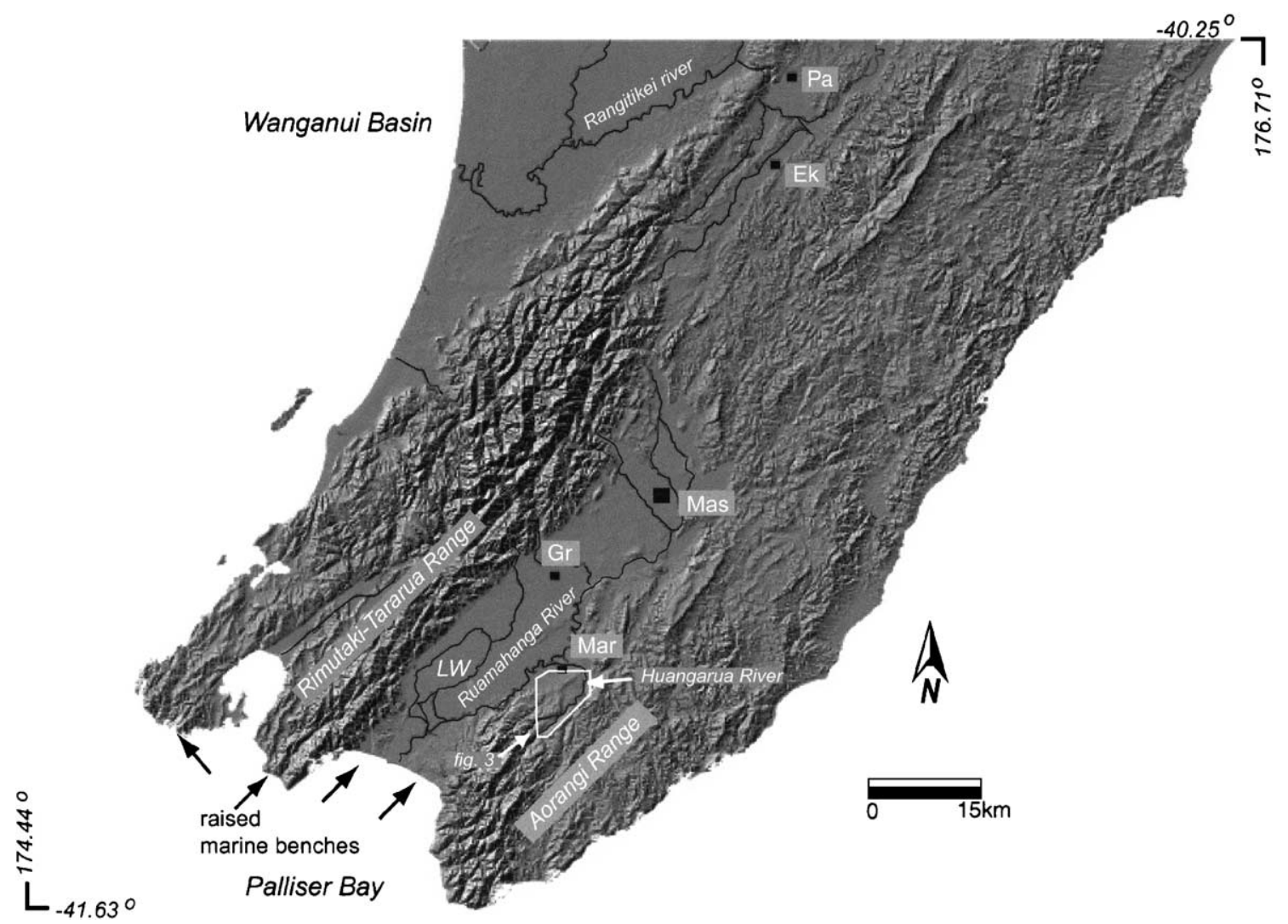

Fig. 2. Major drainages of the southern North Island. The Rimutaki-Tararua Range and the Aorangi Range are the source areas for river gravels deposited throughout the Wairarapa valley. Note the location of the Rangitikei River to the north and the Eketahuna and Pahiatua districts where regional loess and paleosol type sections are located. LW: Lake Wairarapa; Pa: Pahiatua; Ek: Eketahuna; Mas: Masterton; Gr: Greytown; Mar: Martinborough. 


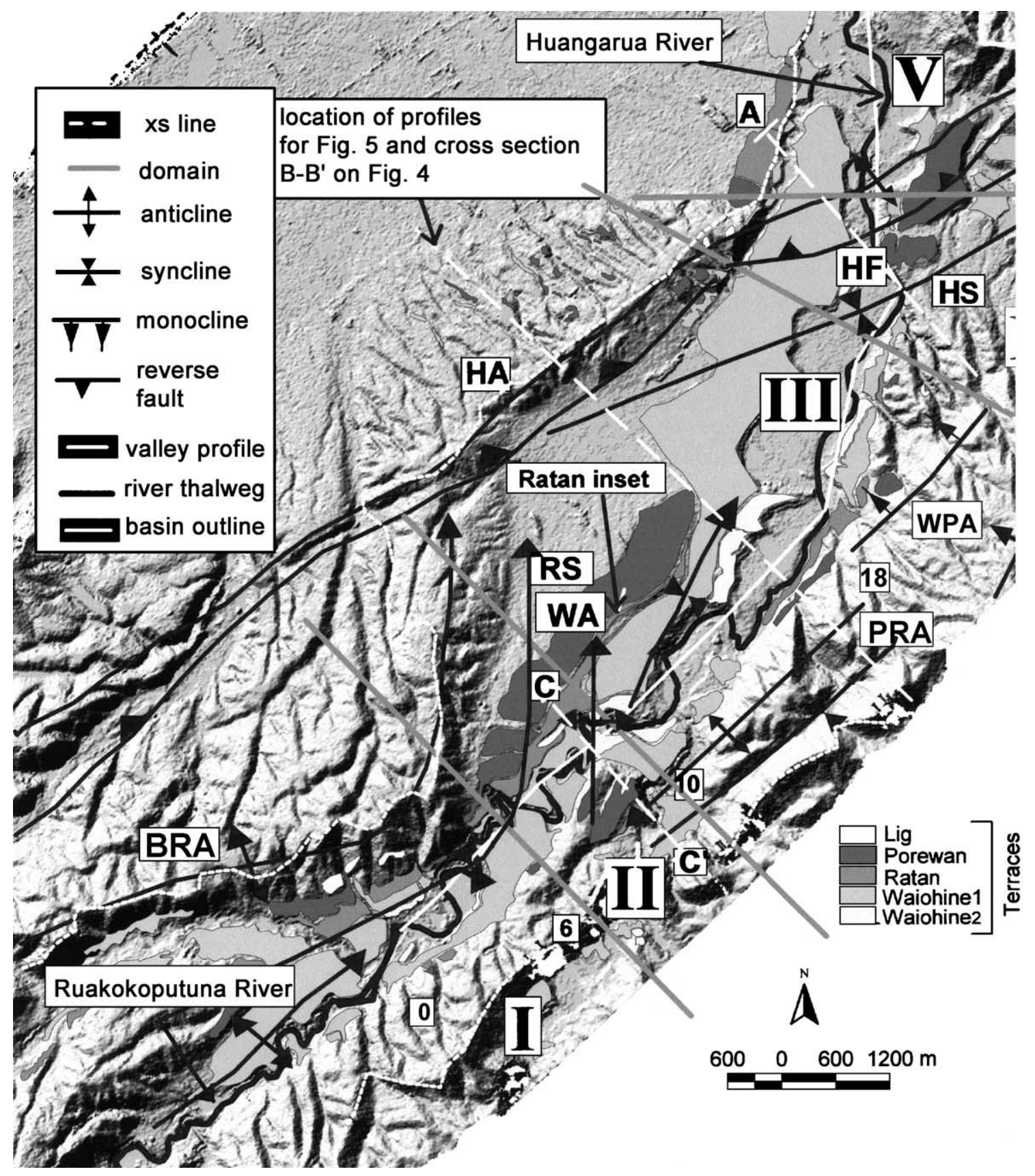

Fig. 3. TOPSAR DEM of Huangarua River valley showing basin outline, the river thalweg, and the valley profile line used to calculate terrace and modern river longitudinal profiles in Fig. 12. Terrace map (where Lig = Last Interglacial surface) and major structures and tectonic domains $(\mathrm{I}-\mathrm{V})$ are shown. RS=Rukokoputuna Syncline; WWA=Wantwood Anticline; WWS = Wantwood Syncline; HS = Huangarua Syncline; $\mathrm{HF}=$ Huangarua fault; and $\mathrm{HA}=$ Harris Anticline. Location of surveyed and DEM profiles in Fig. 5 are shown (B-B'). Note locations of cross sections $\mathrm{A}-\mathrm{A}^{\prime}, \mathrm{B}-\mathrm{B}^{\prime}$, and $\mathrm{C}-\mathrm{C}^{\prime}$ shown in Fig. 4. Also note where the Ratan terrace is inset. 
river embankment exposures, allows for temporal correlation of terraces that range in age from the Last Interglacial $(125 \mathrm{ka})$ to the Holocene.

In this paper, we use detailed analysis of a DEM (Fig. 3) to characterize the geometry of subtle folding of late Quaternary terraces (125 ka to present). These data permit comparison of short-term $(125 \mathrm{ka})$ and long-term (1-2 Ma) patterns of folding and enable us to assess the impact of differential fold growth and climatically induced processes, such as variable sediment flux, on terrace genesis.

\section{Geologic and physiographic setting}

The Hikurangi margin is an active plate boundary that accommodates oblique subduction of the Pacific Plate beneath the Australian Plate at a rate of 38-50 mm/year (Walcott, 1987; De Mets et al., 1994) (Fig. 1). Subduction began in the early Miocene (Ballance, 1976) with the obliquity of relative plate motion increasing through time and space (more oblique farther to the south). A component of shortening normal to the margin is manifested in the Wairarapa fold-and-thrust belt, while the strike-slip component of relative plate motion is reflected in the North Island Dextral Shear Belt (Beanland, 1995). The Wairarapa fault (Grapes, 1991) is the major easternmost fault in this shear belt and has accommodated mainly rightlateral displacement at the surface during the late Quaternary (Fig. 1).

The Wairarapa fold-and-thrust belt lies within the Wairarapa valley and strikes parallel to the present day trend of the Hikurangi margin (Fig. 1). The main basin contains a $20-$ to $30-\mathrm{km}$-wide, ca. $5-\mathrm{km}$ thick sequence of Upper Miocene and younger marine and terrestrial strata. Neogene strata are well exposed along the eastern margin of the basin and overlie basement rocks, which comprise Mesozoic greywackes and argillites of the Torlesse Supergroup (Vella and Briggs, 1971; Collen and Vella, 1984).

Mesozoic greywacke and argillites also form the core of the Axial Ranges and the Aorangi Range where elevations rise up to $1500 \mathrm{~m}$ (Fig. 2). Terrace gravels in the Wairarapa valley consist of detritus shed from these ranges. Loess mantles uplifted marine benches and fluvial terrace treads within the Wairarapa valley (Fig. 2). The paleosol stratigraphy and age of the loess overlying the terrace gravels are keys to correlation of terraces within the study area.

Here we focus on the Huangarua River, which extends east and then southwest approximately 20 $\mathrm{km}$ from its junction with the Ruamahanga River in the Wairarapa valley. Near this junction, the Huangarua River traverses the predominant NE trend of Wairarapa valley and the Wairarapa fold-and-thrust belt. South of Martinborough, the Huangarua River flows in an intermontane basin between two major anticlines: Harris Ridge to the NW and Windy Peak to the SE (Figs. 2-4). This intermontane basin is elongate, narrow in its headwaters, widening out in the middle reach, and narrowing again as it crosses the nose of the northeast-plunging Harris Ridge Anticline (Fig. 3). A major headwater tributary to the Huangarua River is the Ruakokoputuna River (Fig. 3) that has exploited the hinge of the Ruakokoputuna Syncline in its upper reaches (Fig. 3).

\section{Methods}

\subsection{Preparation and sensitivity analysis of altitude data}

Deformation of late Quaternary fluvial terraces in the Huangarua River valley were first described by Lamb and Vella (1987), using two profiles surveyed perpendicular to Harris Ridge Anticline (see Lamb and Vella, 1987, Fig. 8). Similar profiles are depicted in this study (Fig. 5). The surveyed terraces are tilted to the NW at $1-2^{\circ}$. The direction of tilt is consistent with the dip direction in the underlying growth strata (Lamb and Vella, 1987) and indicates active folding of the Huangarua Syncline (Fig. 3). Here, we use the three-dimensional attributes of the TOPSAR topographic data to delineate folding of Huangarua Syncline and to reveal subtler folding along several subsidiary folds in the Huangarua valley (Fig. 3).

Mapping of fluvial terraces was conducted in the field on aerial photographs at a 1:6000 scale. Quaternary stratigraphy throughout the entire $10 \times 50 \mathrm{~km}$ region of the Wairarapa fold-and-thrust belt covered by the DEM was mapped and correlated. We focus 


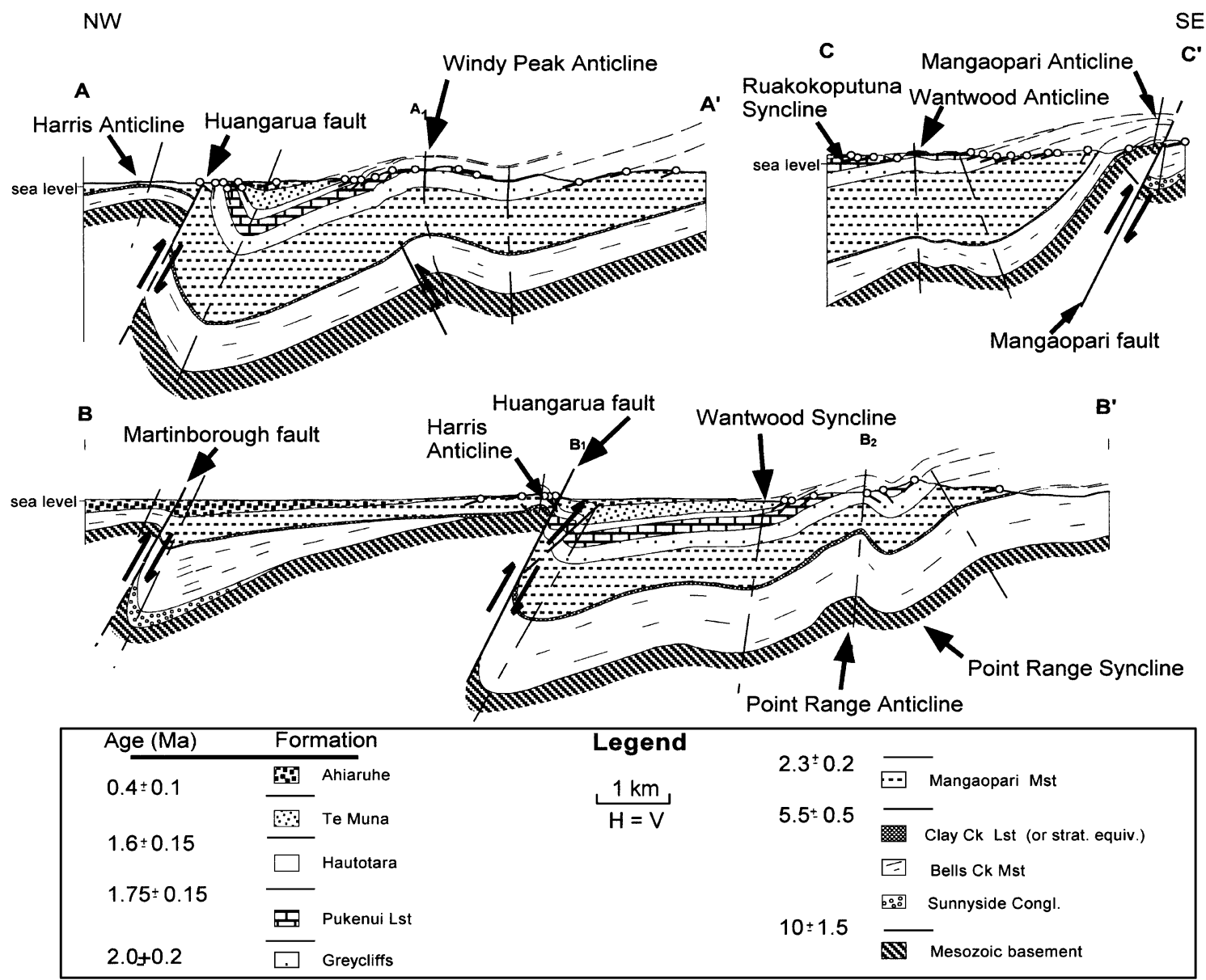

Fig. 4. Cross sections $\mathrm{A}-\mathrm{A}^{\prime}, \mathrm{B}-\mathrm{B}^{\prime}$ and $\mathrm{C}-\mathrm{C}^{\prime}$ derived from outcrop $\left(\mathrm{A}-\mathrm{A}^{\prime}, \mathrm{B}-\mathrm{B}^{\prime}\right.$, and $\left.\mathrm{C}-\mathrm{C}^{\prime}\right)$ and seismic profiles (Nicol et al., in preparation). Seismic-reflection data were depth converted using interval velocities of 1900-2500 ms derived from the stacking velocities. Formation boundaries traced above the ground surface were projected up fold plunge into the plane of the section. Tadpoles indicate the location and dip of bedding, while bold dashed lines indicate fold axial surface traces. Vertical and horizontal scales are equal (modified after Nicol et al., in preparation).

on the Huangarua River valley in the southern portion of the fold belt because terraces and their relation to underlying fold growth strata are well delineated here. Terrace gravels are never more than $3-\mathrm{m}$ thick in the study area and represent the lag left behind as the river abandoned the strath. The loess cover varies in thickness and is up to 4-m thick. We assume, therefore, measurements associated with terrace height at the time of abandonment are accurate to within $4 \mathrm{~m}$ (the maximum thickness of the loess cover).
TOPSAR (synthetic aperture radar) yielded a DEM with a $10-\mathrm{m}$ horizontal resolution and a vertical resolution of less than $2 \mathrm{~m}$. Aerial photos and mapped overlays were digitized and merged with the DEM data in the following manner. In a geographic information system environment, Arc/Info, transformation vectors (four or more) were used to link original features on the aerial photo to the same features on the DEM. Reported root mean square (RMS) errors for this transformation were minimized to $<0.003$. 


\section{Total Station surveyed profile}
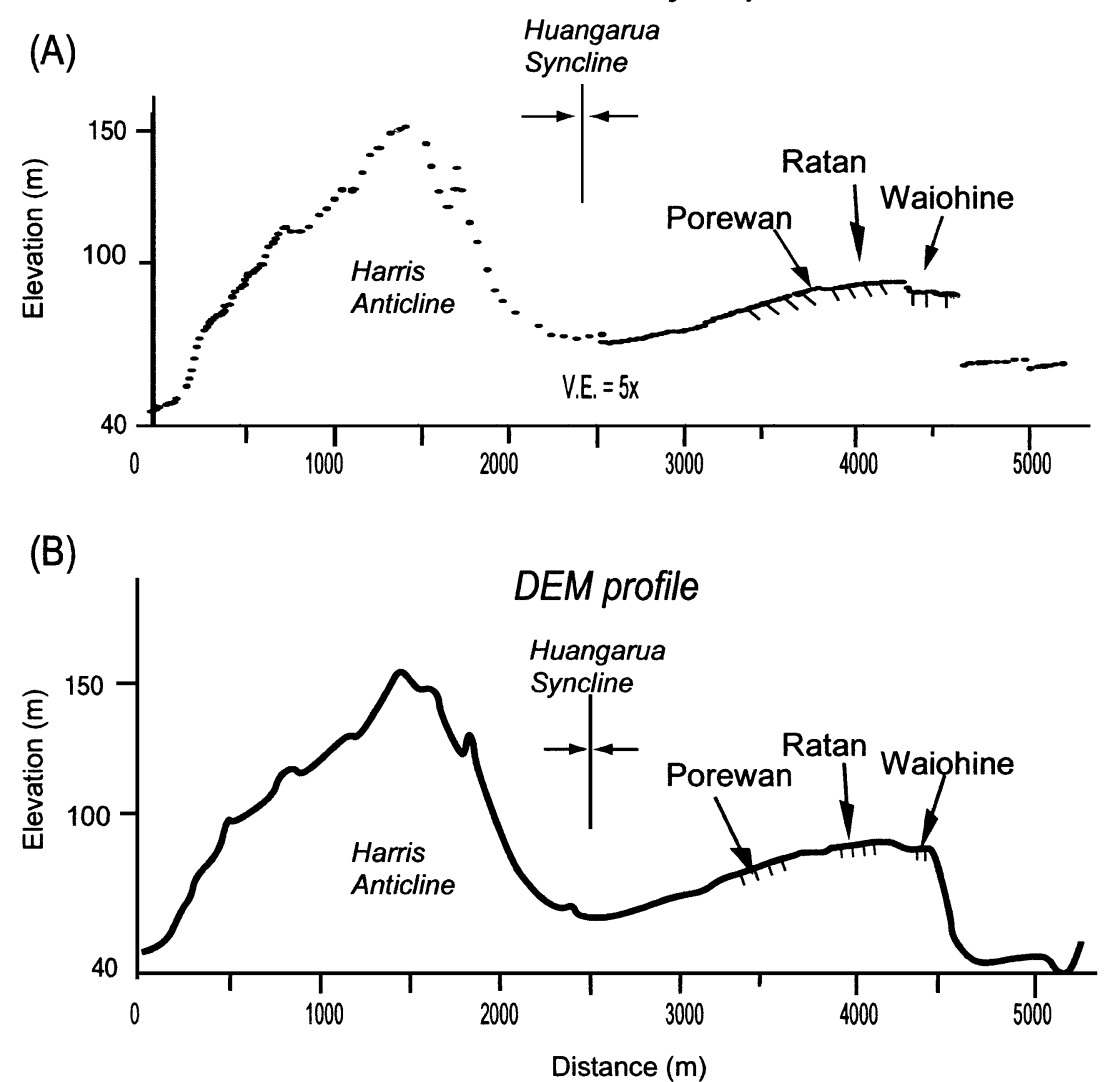

Fig. 5. Topographic profiles across Harris Ridge Anticline and Huangarua Syncline in the Wairarapa valley. The profiles shown are located along the same transect. (A) The top profile shows the survey topographic profile with black lines signifying soil profiles and extent of terrace treads. Data points were taken approximately every 10 to $20 \mathrm{~m}$. (B) The bottom profile is the digital elevation profile with data points every 10 $\mathrm{m}$. Tilt of terrace structures is apparent in both profiles. In addition, the DEM profile includes areas that were not feasible to survey given the steep nature of the terrain.

Topographic profiles were surveyed with a Leica total station and used to test the accuracy of duplicate profiles generated from the DEM. Both the DEM profiles and the profiles surveyed in the field show progressive tilting on the east limb of the Huangarua syncline (Fig. 5). The comparison demonstrates that the DEM yields reliable relative topographic data on broad, open surfaces, such as wide fluvial terraces.

\subsection{Measurement of tectonic tilts}

In order to assess rates of folding based on terrace deformation, subtracting the original depositional gradient from tectonic tilts is important. We initially defined a surface that corresponds with the long-term river valley gradient. A continuous surface representing the average longitudinal valley profile was created based on a best-fit line regressed through the modern river-valley profile. The river-valley profile is deemed preferable to the actual thalweg because it more closely represents the long-term longitudinal profile, corresponding to the broad terrace surfaces, rather than the more sinuous modern thalweg. The valley profile was extrapolated laterally to produce a theoretical river valley datum surface, the altitude of which was subtracted from terrace altitude on a cellby-cell basis. After this subtraction, the resulting residual surface topography was used to delineate tectonic tilting in response to growing folds. 
Tilt rates were calculated by the ratio of degrees of tilt/age of terrace. The associated $1 \sigma$ error results from uncertainties both in the slope and the age of the terraces, as calculated from the OSL dates. Incision rates were calculated using the height of the terrace tread and not the base of the terrace gravels. Incision rates, therefore, reflect incision that occurs after abandonment of the terrace tread and any subsequent deposition, primarily loess accumulation on the tread.

Errors associated with the incision rate analyses include age uncertainties associated with OSL techniques and $\pm 2 \mathrm{~m}$ in vertical height above base level due to the thickness of the loess cover. Relative incision rates were calculated by measuring the elevation difference between various pairs of terraces

Table 1

Luminescence dating results

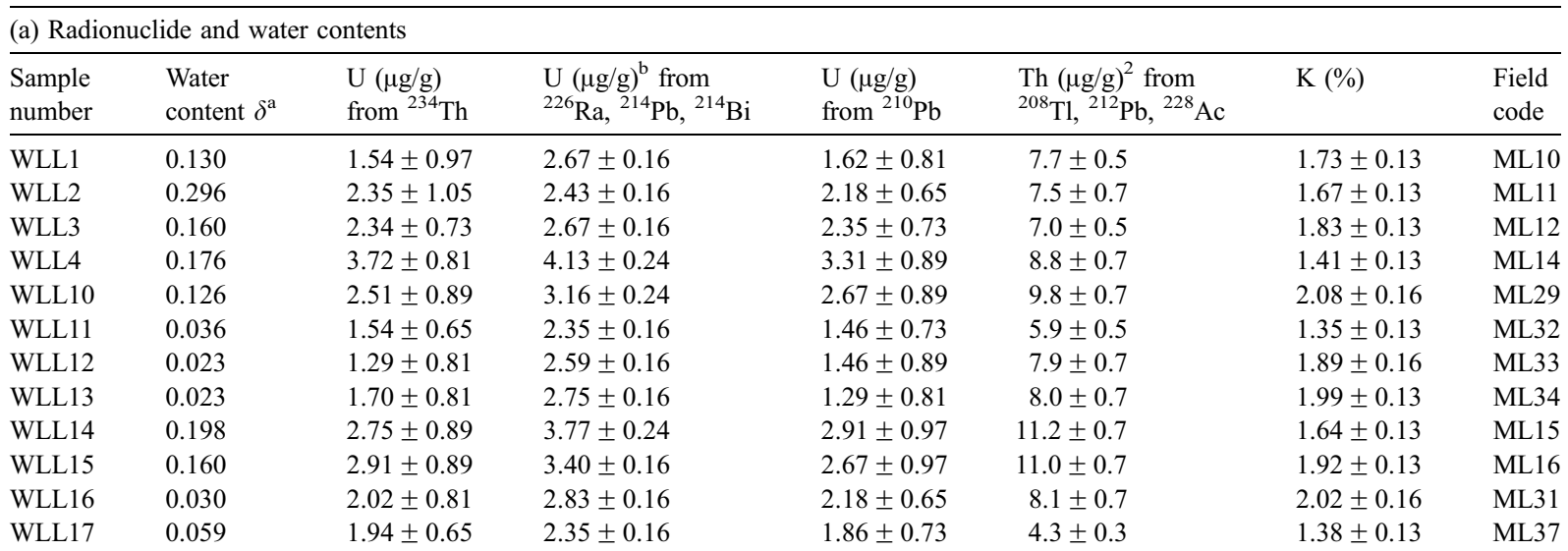

(b) Measured $a$-value and equivalent dose, cosmic doserate, total doserate and OSL age

\begin{tabular}{|c|c|c|c|c|c|c|c|c|}
\hline $\begin{array}{l}\text { Sample } \\
\text { number }\end{array}$ & $a$-value & $D_{\mathrm{e}}$ (Gyears) & $D_{\mathrm{c}}(\text { Gyears } / \mathrm{ka})^{\mathrm{c}}$ & $\begin{array}{l}\mathrm{d} D / \mathrm{d} t \\
\text { (Gyears/ka) }\end{array}$ & OSL-age (ka) & $\begin{array}{l}\text { Site } \\
\text { number }^{d}\end{array}$ & $\mathrm{Age}^{\mathrm{e}}$ & $\begin{array}{l}\text { Field } \\
\text { code }\end{array}$ \\
\hline WLL1 & $0.07 \pm 0.01$ & $66.4 \pm 1.9$ & $0.193 \pm 0.010$ & $3.58 \pm 0.21$ & $18.5 \pm 1.2^{\mathrm{f}}$ & 2 & $\mathrm{Oh}$ & ML10 \\
\hline WLL2 & $0.12 \pm 0.02$ & $72.5 \pm 4.3$ & $0.176 \pm 0.009$ & $3.26 \pm 0.31$ & $22.2 \pm 2.5$ & 2 & $\mathrm{Oh}$ & ML11 \\
\hline WLL3 & $0.07 \pm 0.01$ & $100.7 \pm 3.7$ & $0.166 \pm 0.008$ & $3.46 \pm 0.22$ & $29.1 \pm 2.1$ & 2 & $\mathrm{Ra}$ & ML12 \\
\hline WLL4 & $0.07 \pm 0.02$ & $116.8 \pm 7.8$ & $0.188 \pm 0.009$ & $3.74 \pm 0.32$ & $31.3 \pm 3.4$ & 1 & $\mathrm{Ra}$ & ML14 \\
\hline WLL10 & $0.10 \pm 0.02$ & $59.3 \pm 3.1$ & $0.196 \pm 0.010$ & $4.66 \pm 0.33$ & $12.7 \pm 1.1$ & 11 & $\mathrm{Oh}$ & ML29 \\
\hline WLL11 & $0.08 \pm 0.02$ & $26.5 \pm 1.4$ & $0.200 \pm 0.010$ & $3.32 \pm 0.21$ & $7.95 \pm 0.65^{\mathrm{f}}$ & 3 & $\mathrm{~W}$ & ML32 \\
\hline WLL12 & $0.08 \pm 0.01$ & $44.7 \pm 4.2$ & $0.200 \pm 0.010$ & $4.29 \pm 0.19$ & $10.4 \pm 1.1^{\mathrm{f}}$ & 4 & W & ML33 \\
\hline WLL13 & $0.09 \pm 0.01$ & $48.1 \pm 5.1$ & $0.200 \pm 0.010$ & $4.59 \pm 0.18$ & $10.5 \pm 1.2^{\mathrm{f}}$ & 5 & W & ML34 \\
\hline WLL14 & $0.06 \pm 0.02$ & $298.9 \pm 12.7$ & $0.182 \pm 0.009$ & $3.85 \pm 0.35$ & $77.6 \pm 7.7^{\mathrm{f}}$ & 1 & Po & ML15 \\
\hline WLL15 & $0.10 \pm 0.03$ & $335.0 \pm 17.7$ & $0.174 \pm 0.009$ & $4.57 \pm 0.43$ & $73.3 \pm 7.9$ & 1 & Po & ML16 \\
\hline WLL16 & $0.07 \pm 0.02$ & $62.5 \pm 5.6$ & $0.193 \pm 0.010$ & $4.41 \pm 0.27$ & $14.2 \pm 1.5$ & 6 & $\mathrm{Oh}$ & ML31 \\
\hline WLL17 & $0.09 \pm 0.01$ & $16.1 \pm 0.9$ & $0.200 \pm 0.010$ & $3.14 \pm 0.15$ & $5.12 \pm 0.37$ & 7 & W & ML37 \\
\hline
\end{tabular}

${ }^{\text {a }}$ Ratio wet sample to dry sample weight. Errors assumed $50 \%$ of $(\delta-1)$.

${ }^{\mathrm{b}} \mathrm{U}$ and Th content is calculated from the error weighted mean of the isotope equivalent contents.

${ }^{c}$ Contribution of cosmic radiation to the total doserate, calculated as proposed by Prescott and Hutton (1995).

${ }^{\mathrm{d}}$ For site number locations, see Fig. 7.

e Age designations are based on landscape position and OSL dates. Po=Porewa loess, Ra $=$ Rata loess, Oh=Ohakea loess, and $\mathrm{W}=$ Waiohine-aged loess.

${ }^{\mathrm{f}}$ A minor radioactive disequilibrium was detected in samples WLL1, WLL11, WLL12, WLL13, and WLL14 (as shown in panel (a)). The given dose rates $\mathrm{d} D / \mathrm{d} t$ and OSL-ages are not corrected for that, i.e., calculated under equilibrium assumption, using the $\mathrm{U}$-content from ${ }^{226} \mathrm{Ra}$, ${ }^{214} \mathrm{~Pb},{ }^{214} \mathrm{Bi}$ isotopes as representative. Any attempt to correct for the disequilibrium would result in age estimates about $10-15 \%$ higher than given in the table for these samples. 
and dividing the elevation difference by the age difference. Absolute tilt and incision rates were calculated for each transect and averaged for each domain.

\subsection{Optically stimulated luminescence}

Optically Stimulated Luminescence dating has been used to determine the deposition ages of 15 sites. Results are summarized in Table 1a,b. The paleodose, i.e., the radiation dose accumulated in the sample after the last light exposure (assumed at deposition), was determined by measuring the blue luminescence output $(410 \mathrm{~nm}$ band, filters Schott BG39 + Kopp 5-58) during infrared optical stimulation. This selectively stimulates the feldspars in the fine grain fraction $(4-11 \mu \mathrm{m})$ used for dating. The newly developed single aliquot regenerative protocol (SAR) was applied, using $270{ }^{\circ} \mathrm{C} / 2$-min preheat times and 100-s stimulation intervals for four regenerated dose points. All measurements were carried out on Victoria Universities Riso TL-DA15, equipped with an ${ }^{90} \mathrm{Sr} /{ }^{90} \mathrm{Y}$ beta source for irradiation and an IR diode array for stimulation. Fading test and $a$-value determination and were carried out by means of a conventional multiple aliquot approach.

Radionuclide contents were measured by low-level gammaspectrometry by the National Radiation Laboratory (NRL), Christchurch, New Zealand. The doserate estimates, used together with the paleodose measurement for age calculations, are based on the activity concentration of the nuclides ${ }^{40} \mathrm{~K},{ }^{208} \mathrm{Tl}$, ${ }^{212} \mathrm{~Pb},{ }^{228} \mathrm{Ac},{ }^{210} \mathrm{~Pb},{ }^{214} \mathrm{Bi},{ }^{214} \mathrm{~Pb},{ }^{226} \mathrm{Ra}$ and ${ }^{234} \mathrm{Th}$, as reported by the NRL. The latter five of these isotopes allow, if applicable, an estimate of the degree of radioactive disequilibrium in the uranium decay chain.

\section{Terrace stratigraphy, ages, and correlation}

The cover-bed stratigraphy overlying terrace straths comprises gravels, loess, and paleosols. Mesozoic greywacke clasts dominate the upper-Quaternary fluvial gravels and provide little means of distinguishing terrace units. Therefore, fluvial terraces have been differentiated based on the loess-paleosol stratigraphy, the age of loess deposits, the weathering character- istics of the gravels, and, to some extent, the relative height of the terrace above local base level.

Terrace surfaces have been dated in two distinct ways and were used to quantify river response to late Quaternary fold growth. First, absolute dating of loess permits temporal correlation of individual terrace remnants, both locally and between drainage basins. Second, we correlate the loess and paleosol sequence in the Huangarua valley to a well-established regional stratigraphy (Palmer, 1982; Palmer and Vucetich, 1989). Based on integrated loess stratigraphy, tephrochronology, and palynological data, a long history of Quaternary climatic change in the southern North Island has been created (Alloway et al., 1992; Lewis and Mildenhall, 1985; McGlone et al., 1993; Palmer and Pillans, 1996; Palmer and Vucetich, 1989; Pillans et al., 1993; Shulmeister, 1999) that serves as an additional time calibration on the local loess record.

Episodes of loess accumulation have been linked to increased quartz accumulation rates recorded in Southern Hemisphere marine sediments from deepsea and ice-core records of eolian sediment (Alloway et al., 1992; De Angelis et al., 1987; Nelson et al., 1985; Stewart and Neall, 1984; Theide, 1979). In New Zealand, loess is derived from the expanded coastal plain during lower sea level, from an expansion of arid source areas (particularly from the NW) (Wanganui Basin: Fig. 2), during glacial stages, and from the beds of rivers and their flood plains (Cowie, 1964) at times of sediment aggradation (Fig. 6).

In southern Wairarapa, three loess units were deposited during the last glacial-interglacial climate cycle. In order of deposition, these units are referred to as Porewa, Rata, and Ohakea loess in accordance with previous work (Cowie, 1964; Ghani, 1978; Milne, 1973; Palmer, 1982). In addition, small pockets of loess are also present on the youngest (Waiohine) terrace, which post-dates accumulation of Ohakea loess. Loess is described here based on data from over a dozen $4 \times 4 \times 5 \mathrm{~m}$ trenches and five river bank exposures excavated throughout the study area (Fig. 7). OSL dates were obtained from 11 sites (Fig. 8). These dated sites are correlated to trench sites in the Huangarua River valley without OSL dates (e.g., sites 8 and 9). Table 2 shows the location of the trenches with OSL dates and our loess stratigraphy correlated to basins to the north and west (Fig. 2) 

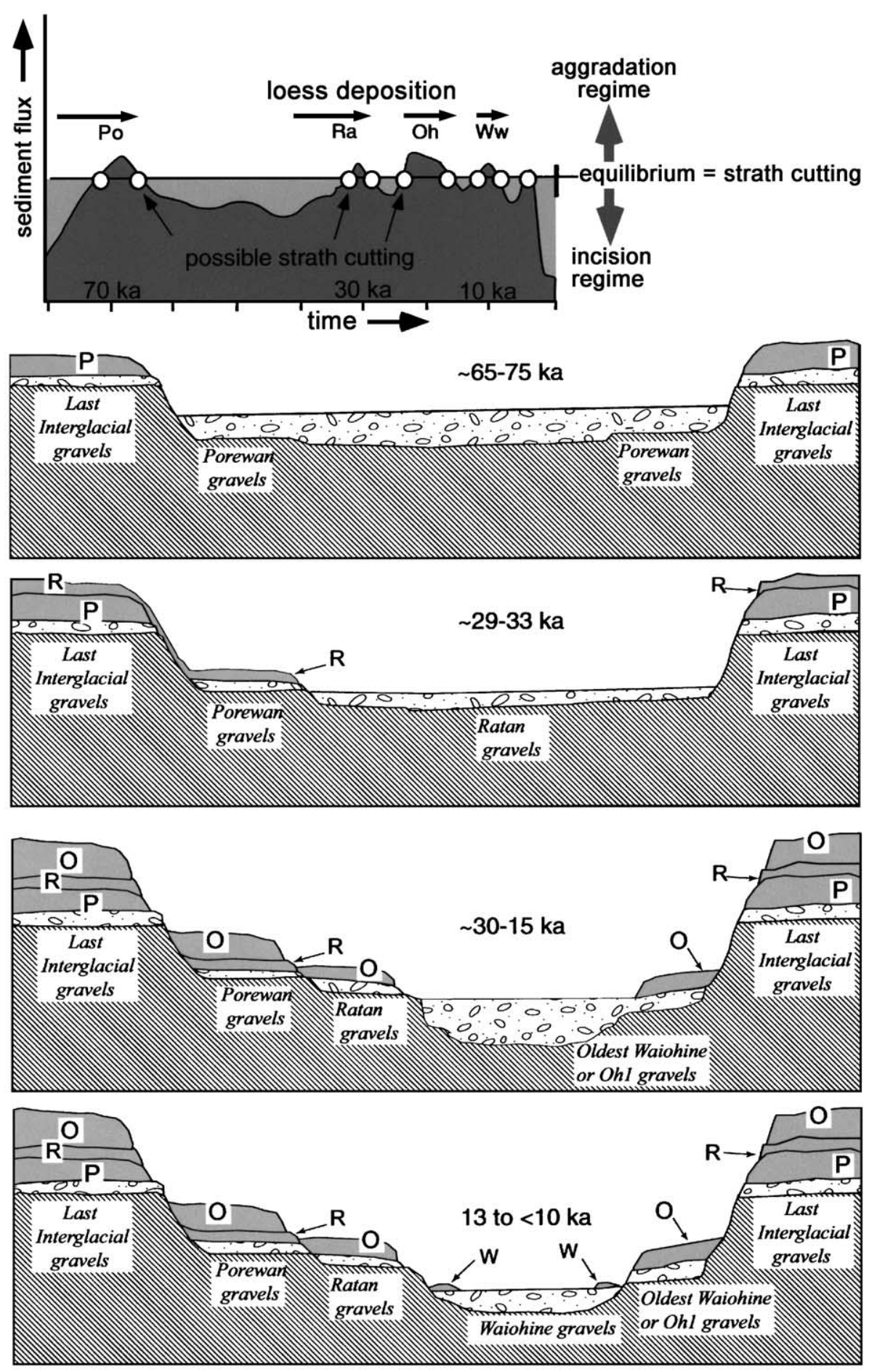

Fig. 6. Sketch of temporal evolution of loess depositional sequence shown here from the Last Interglacial to $\sim 10$ ka. Shaded units represent loess deposits. Contemporaneous gravels are shown in the channel. $\mathrm{P}=$ Porewa loess; $\mathrm{R}=$ Rata loess; $\mathrm{O}=$ Ohakea loess, and $\mathrm{W}=\mathrm{Waiohine}-\mathrm{aged}$ loess. 


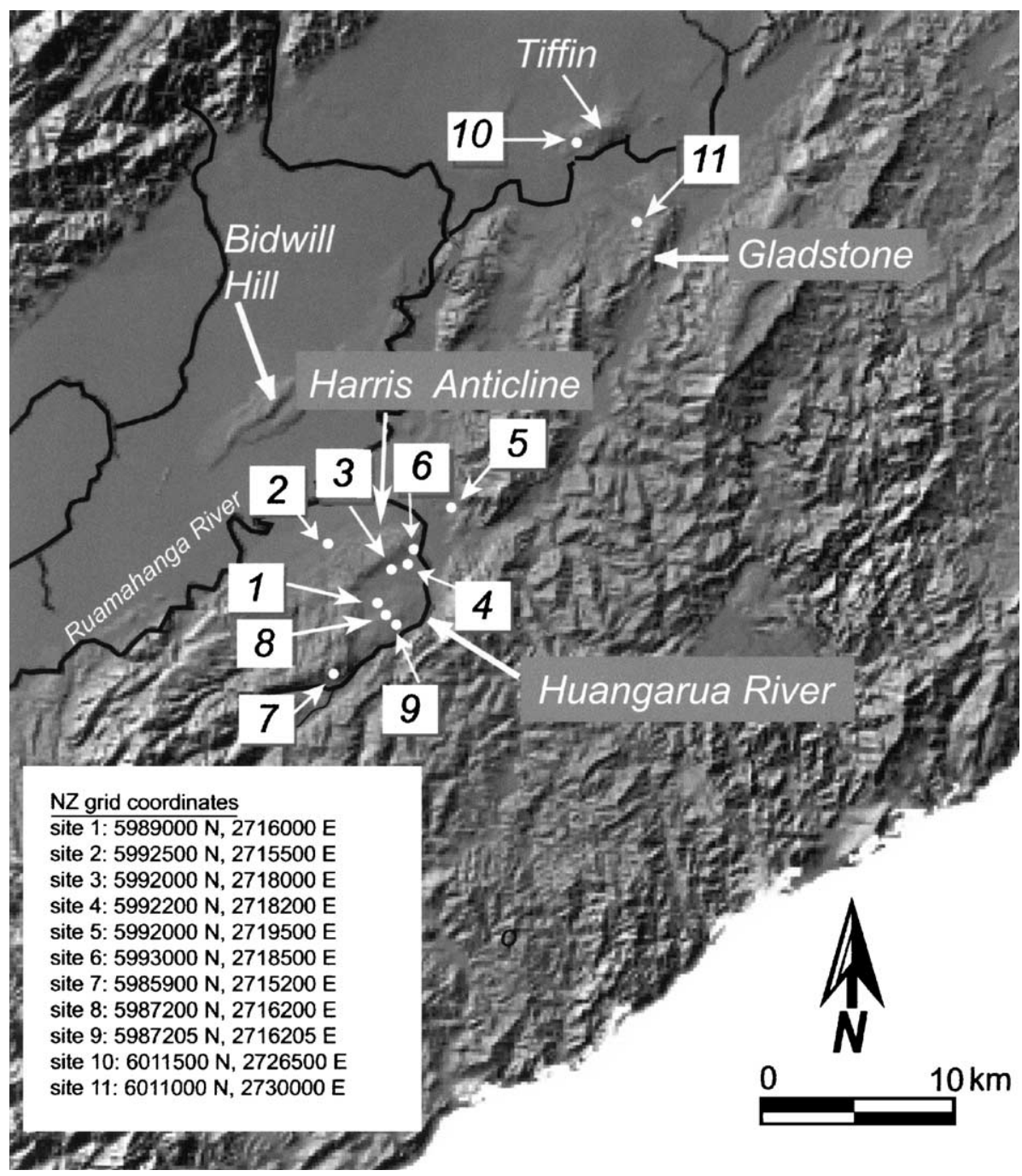

Fig. 7. Location map for soil trenches and auger holes. See Fig. 8 and Table 1 for descriptions and OSL dates.

in the Eketahuna region (Vella et al., 1988) and the Rangitikei District (Cowie, 1964; Cowie and Milne, 1973; Milne, 1973; Milne and Smalley, 1979; Palmer, 1982; Palmer and Pillans, 1996; Palmer and Vucetich, 1989).

Describing the nomenclature associated with loess stratigraphy is important here as it can be confusing. The loess unit is named for a particular temporal event. For example, the Rata loess is correlative in time to the Ratan gravel deposition but is found overlying older terrace gravels. To further illustrate this point; the Porewa loess overlies the last Iinterglacial Surfacesurface, the Rata loess overlies Porewan gravels, and the Ohakea loess overlies the Ratan terrace (Fig. 6). We adopt this same nomenclature in order to be consistent with other New Zealand studies.

A well-established Quaternary paleosol stratigraphy (Leamy et al., 1973; Palmer, 1982; Palmer and Pillans, 1996) throughout New Zealand has been used to correlate to warming climate phases within glacialinterglacial climate cycles. In the southern North 


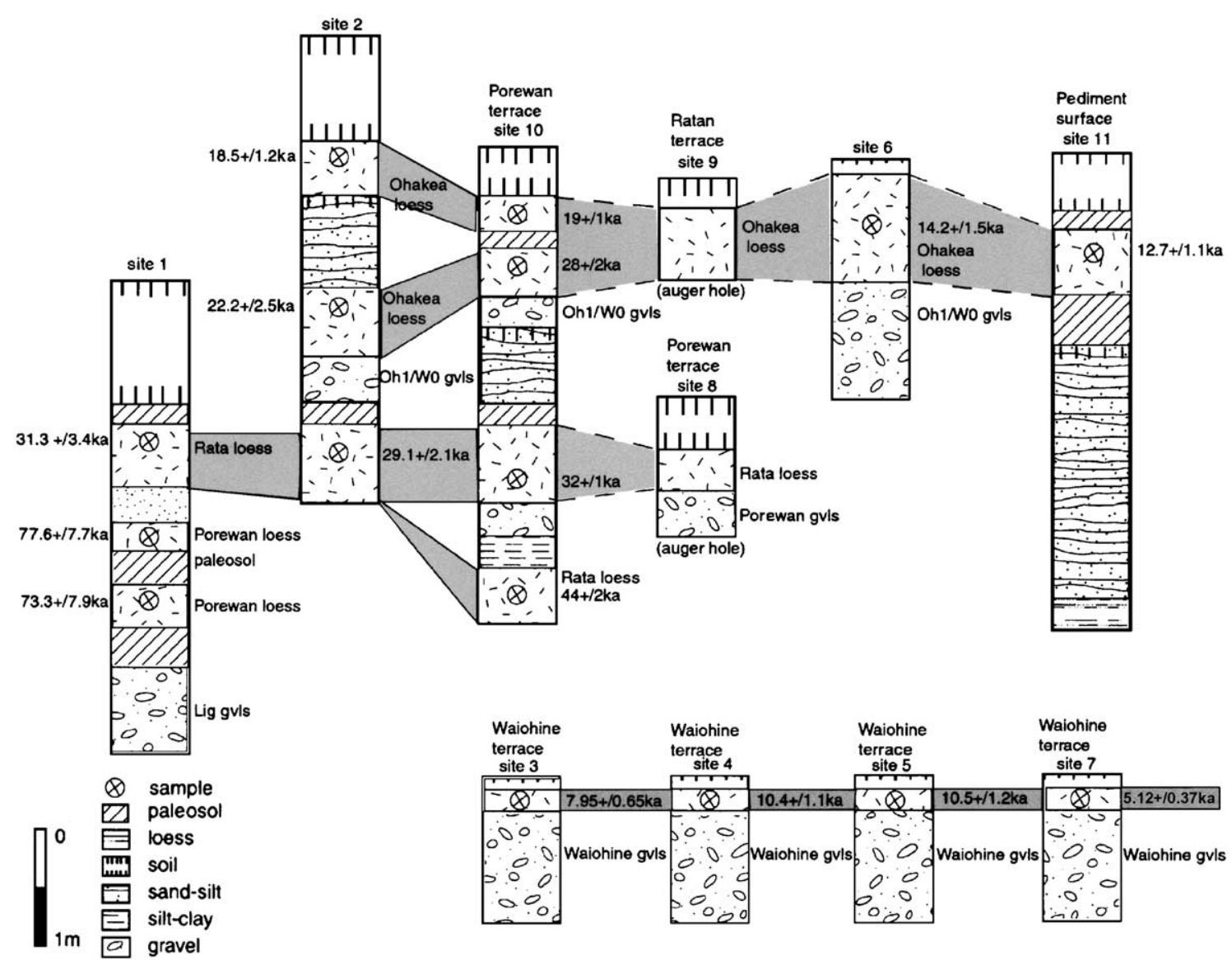

Fig. 8. Correlation chart for soil profiles throughout the Wairarapa River valley. See Fig. 7 for location of sites and Table 1 for OSL data. Crosshatched circles show sample locations within the loess unit. W0 = oldest Waiohine terrace or Oh1= Ohakea 1 (after Milne, 1973), gvl=gravel, and Lig = Last Interglacial.

Island, palynological records and soil geochemistry support the interpretation that paleosols reflect warming (or warmer) climatic conditions (Alloway et al., 1992; Palmer and Pillans, 1996; Vella et al., 1988). In this way, paleosol units are used as marker horizons between major loess units and reflect interstadial phases of the climate cycle.

The last interglacical ages of surfaces in the study area are based on uplifted interglacial shorelines inferred by Ghani (1978), well-preserved pollen and diatom flora data (Palmer and Vucetich, 1989), overlying loess units (Porewa, Rata, and Ohakea, Palmer and Vucetich, 1989, and this study), and regional correlations to coastal outcrops in western Palliser Bay where two luminescence ages and an amino acid racismisation age of a tree stump constrains the last interglacial age (Shulmeister et al., in preparation).

\subsection{Porewa terrace}

Fluvial terraces and loess of Porewan age are mapped throughout the southern North Island (Kaewyana, 1980; Milne, 1973; Palmer, 1982; Palmer and Vucetich, 1989; Vella, 1963; Vucetich et al., 1996). Thick accumulations ( $>3 \mathrm{~m}$ ) of Porewan-aged gravels are characteristic of terraces in the north and west of the southern Wairarapa (Fig. 2). This trend is also true for areas immediately adjacent to the Axial Ranges (Grapes, 1991; Milne, 1973) and in regions 
Table 2

Correlation of Huangarua stratigraphy and loess units with drainage basins throughout southern North Island, New Zealand

\begin{tabular}{|c|c|c|c|c|c|}
\hline $\begin{array}{l}\text { Huangarua }^{\mathrm{a}} \\
\text { stratigraphy }\end{array}$ & Age (years) & Source of age data & $\begin{array}{l}\text { Location } \\
\text { (site number) }\end{array}$ & Rangitikei $^{\mathrm{a}}$ & Eketahuna-Pahiatua ${ }^{a}$ \\
\hline Ww loess & $\begin{array}{l}5.12 \pm 0.37 \mathrm{ka} \\
7.95 \pm 0.65 \mathrm{ka} \\
10.4 \pm 1.1 \mathrm{ka} \\
10.5 \pm 1.2 \mathrm{ka}\end{array}$ & $\begin{array}{l}\text { OSL dates } \\
\text { This study (Table 1) }\end{array}$ & $\begin{array}{l}7 \\
3 \\
4 \\
5\end{array}$ & Ohakea loess & Hukanui surface \\
\hline Kawakawa tephra & $22.6 \mathrm{ka}$ & $\begin{array}{l}\text { Glass shards, } \\
\text { Wilson et al., } 1988\end{array}$ & & $\begin{array}{l}\text { Ohakea loess with } \\
\text { Kawaka tephra }\end{array}$ & $\begin{array}{l}\text { Hukanui surface with } \\
\text { Kawaka tephra }\end{array}$ \\
\hline Ohakea loess & $\begin{array}{l}12.7 \pm 1.1 \mathrm{ka} \\
14.2 \pm 1.5 \mathrm{ka} \\
18.5 \pm 1.2 \mathrm{ka} \\
19.0 \pm 1 \mathrm{ka} \\
22.2 \pm 2.5 \mathrm{ka} \\
28.0 \pm 2.0 \mathrm{ka}\end{array}$ & $\begin{array}{l}\text { OSL dates } \\
\text { This study (Table 1) }\end{array}$ & $\begin{array}{r}11 \\
6 \\
2 \\
10 \\
2 \\
10\end{array}$ & & \\
\hline Weak paleosol & Bidwill Hill & $1,2,11$ & & Weak paleosol & Weak paleosol \\
\hline Rata loess & $\begin{array}{l}29.1 \pm 2.1 \mathrm{ka} \\
31.3 \pm 3.4 \mathrm{ka} \\
32.0 \pm 1.0 \mathrm{ka}\end{array}$ & $\begin{array}{l}\text { OSL dates } \\
\text { This study (Table 1) }\end{array}$ & $\begin{array}{r}2 \\
1 \\
10\end{array}$ & Rata loess & $\begin{array}{l}\text { Pukewhai surface } \\
\text { and loess }\end{array}$ \\
\hline Paleosol & Lake Ferry(?) & $1,2,11$ & & $\begin{array}{l}\text { Andesitic tephra } \\
\text { and Paleosol }\end{array}$ & $\begin{array}{l}\text { Makakahi Tephric } \\
\text { Paleosol }\end{array}$ \\
\hline Porewa loess & $\begin{array}{l}73.3 \pm 7.9 \mathrm{ka} \\
77.6 \pm 7.7 \mathrm{ka}\end{array}$ & $\begin{array}{l}\text { OSL study } \\
\text { This study (Table 1) }\end{array}$ & & $\begin{array}{l}\text { Porewa surface } \\
\text { and loess }\end{array}$ & $\begin{array}{l}\text { Eketahuna surface } \\
\text { and loess }\end{array}$ \\
\hline
\end{tabular}

${ }^{a}$ See Fig. 7 for location of sites and Fig. 8 for stratigraphic columns in the Huangarua Valley. See Fig. 2 for locations of Rangitikei and Eketahuna. Rangitikei from Milne and Smalley (1979) and Milne (1973) and Eketahuna-Pahiatua from Vella et al. (1988).

of slow tectonic uplift (Vella et al., 1988). However, in this study area, Porewan-aged gravels are generally a thin veneer $(<3 \mathrm{~m})$ overlying Tertiary bedrock. The terrace gravels can be of variable thickness, from $<1$ $\mathrm{m}$ on structural highs to $\sim 3 \mathrm{~m}$ in structural lows. Porewan gravels were also encountered in trenches at depths of $\sim 3.5 \mathrm{~m}$. The basal contact of the Porewan gravels, where exposed, is planar and unconformable. In the Huangarua River valley, we delineate the Porewan terrace as a strath terrace based on the following characteristics: planar basal surface cut on bedrock, commonly with an angular unconformity, and overlain by a thin gravel lag $(0-3 \mathrm{~m})$.

In the southern Wairarapa, Porewa loess typically rests conformably on last interglacial (Lig) marine benches and fluvial surfaces, which comprise reddishbrown paleosol, pebble-gravels, or lacustrine sediments (Palmer and Vucetich, 1989; Warnes, 1989). In the Rangitikei region (Fig. 2), Milne (1973) found fine-grained weathered residues of andesitic ash from the Middle Tongariro Tephras dated at $\sim 60$ kyears BP within a regionally prevalent paleosol in the top of the loess. Apparently, primary loess deposition is likely to occur during the marine isotope stage 4 regression and low stand (Palmer and Vucetich, 1989). This is consistent with our OSL ages of $73 \pm 8$ and $78 \pm 8$ ka within the Porewa loess (Tables 1 and 2; Fig. 8).

\subsection{Rata terrace}

Fluvial terrace treads and loess of Ratan age have been mapped to the north in the Eketahuna district (Vella et al., 1988) and in the Rangitikei River basin (Milne, 1973) (Fig. 2). In these locations, Ratan gravels are upward of 4-m thick; and a single (younger) loess layer, the Ohakea loess, caps the gravels. In our field area, Ratan terrace gravels are rarely exposed and usually expressed as thin $(<2 \mathrm{~m})$ veneers. The Ratan terrace is inset below the Porewan terrace (Fig. 3) in the middle reach of the river with generally $<2 \mathrm{~m}$ vertical separation. In areas adjacent to hillsides, the Ratan terrace tread is commonly buried by younger alluvial fans.

First described in the Rangitikei District (Cowie and Milne, 1973; Milne, 1973) (Fig. 2), the Rata loess 
has been regionally correlated to loess exposures in the Wairarapa (Milne and Smalley, 1979). Rata loess is distinguished from the overlying Ohakea loess (Palmer, 1982) by its stronger orange color and siltclay-loam texture (Palmer, 1982).

Source areas for Rata loess were restricted in lateral extent compared to both Porewan and Ohakean climate phases because of higher local sea level (Palmer and Vucetich, 1989). OSL dates for the Rata loess range from $\sim 29$ to $32 \mathrm{ka}$, although some dates as old as $44 \mathrm{ka}$ were obtained from samples correlated with the Rata loess (Table 1; Fig. 8). A weak paleosol (the Bidwill Hill paleosol: Palmer, 1982) was developed in the top of the loess in three out of four excavations (Figs. 7 and 8).

\subsection{Ohakea terrace}

Ohakea-aged terraces are located in the study area, but we have chosen to map them as part of the Waiohine suite of terraces in order to keep the nomenclature simple and consistent with previous studies (Vella et al., 1988). However, we delineate the Ohakea loess because it was the most extensive

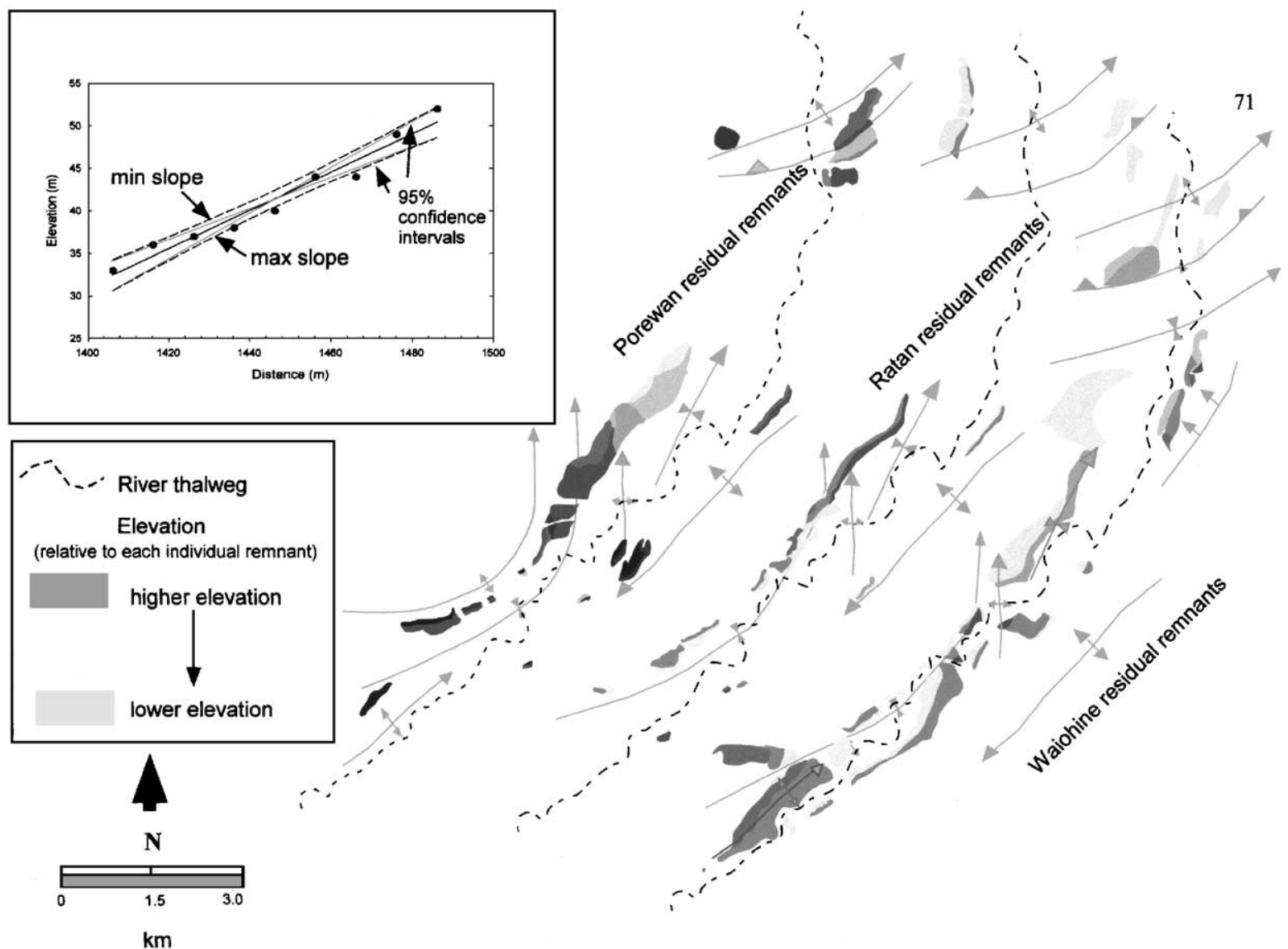

Fig. 9. Residual terrace remnants calculated by subtracting river datum surface. Darker shades of gray indicate higher elevation anomalies and lighter shades of gray indicate lower elevation anomalies. The shading is relative to each individual remnant in order to shown subtle differences in elevation. Inset shows an example of $95 \%$ confidence intervals and regression line through elevation data used to calculate slopes of a terrace remnant. The minimum slope and the maximum slope within the $95 \%$ confidence intervals shows the error associated with the slope of the regression line. 
loess in the study area and has particular climatic significance, as discussed later.

Ohakea loess, first described in the Rangitikei District (Cowie and Milne, 1973; Milne, 1973) (Fig. 2), has been correlated to loess units in the Wairarapa valley (Palmer, 1982). It is the most extensive loess unit overlying terrace gravels. A prominent rhyolitic airfall tephra, Aokautere Ash airfall tephra of the Kawakawa Tephra Formation, radiocarbon dated at 22.6 ka BP (Wilson et al., 1988), produces a marker bed within the loess. This ash is also found microscopically as concentrations of glass shards, but occurs mostly as a $2.0-\mathrm{m}$-thick white layer about one-third of the way above the base of the loess (Warnes, 1989). Thickness of the Ohakea loess ranges from 0.3 to $20 \mathrm{~m}$. The loess is a mottled dull yellowish brown color without vertical cracks (Fig. 8). Overlying the loess is a fragipan with polygonal structure and vertical cracks (Fig. 8). In the Huangarua River valley, Ohakea loess is found overlying Rata loess and Ratan gravels (Fig. 8).

Previous results have shown that the Ohakea loess was deposited between 28 and $12 \mathrm{ka}$ BP based on radiocarbon dating of wood near the base of Ohakea loess (Milne and Smalley, 1979) and on the degree of soil development in overlying deposits (Alloway, 1989; Milne and Smalley, 1979). Our OSL data consist of several samples that yielded dates ranging from about 28 to $\sim 13 \mathrm{ka}$ (Tables 1 and 2).

\subsection{Waiohine terrace}

Waiohine terraces are best expressed in the Rangitikei Valley (the Waiohine is called the Ohakean terrace by Milne (1973), although similarly aged terraces are abundant throughout the southern North Island) (Kaewyana, 1980; Palmer, 1982; Vella, 1963; Vella et al., 1988; Alloway et al., 1992). Milne (1973) distinguished three terraces using the name Ohakean $\left(\mathrm{Oh}_{1}, \mathrm{Oh}_{2}\right.$, and $\mathrm{Oh}_{3}$ from oldest to youngest). New radiocarbon dates have refined Milne's original ages to ca. 18, 12, and $10 \mathrm{ka}$ (Marden and Neall, 1990; Pillans et al., 1993). In Rangitikei, the youngest $\left(\mathrm{Oh}_{3}\right)$ surfaces are underlain by gravels, which are dated at 9450 years BP. (Pillans et al., 1993).

In the Wairarapa valley, Waiohine terrace gravels are equivalent to Ohakean gravels and are coarse, angular to subrounded, moderately sorted, and light

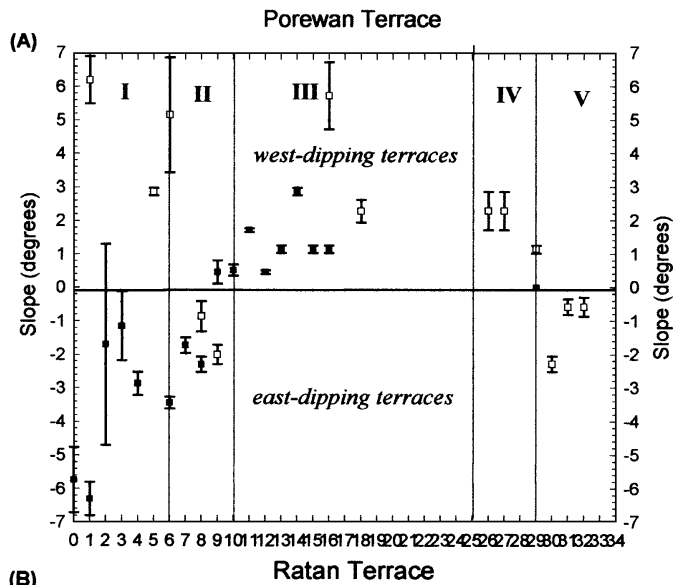

(B)
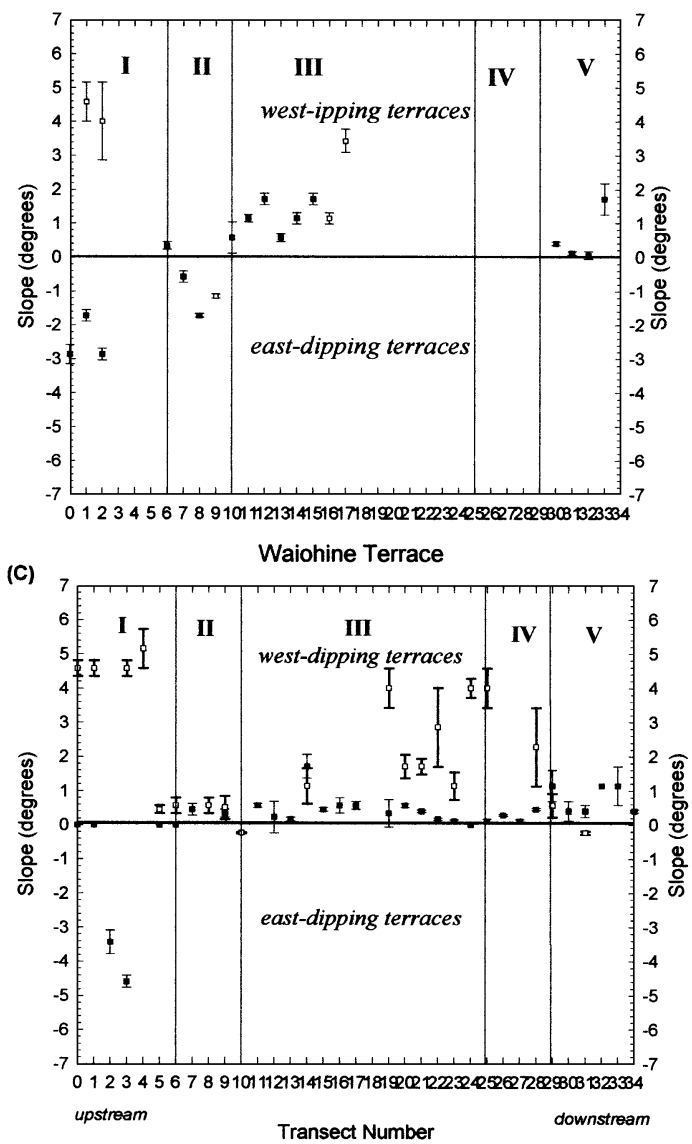

Fig. 10. (A) Slope values for Porewan terrace remnants for each transect. (B) Slope values for Ratan terrace remnants for each transect. (C) Slope values for Waiohine terrace remnants for each transect. Error analyses are discussed in the text. The average tilt (degrees) calculated for each tectonic domain and each age of terraces on each side of the river. 
blue-gray in color. The gravels also lack the ironmanganese staining and weathering rinds of older Porewan- and Ratan-aged gravels. Terrace gravels overlie Tertiary bedrock in most locations with a planar and unconformable basal contact on the Waiohine gravels. We characterize the Waiohine terrace as a strath terrace because of the relative thin veneer of gravels and the planar, low relief basal contact that is cut on bedrock.

In the Huangarua River valley, we distinguish three Waiohine terraces; however, we only have OSL dates for the second oldest and most extensive tread. For the remainder of this paper, "Waiohine" terrace refers only to this most extensive terrace tread. After Waiohine terrace abandonment, the Waiohine loess was deposited most often within paleochannels.

Few exposures of Waiohine loess have been found in the study area. When the loess is found, it is never more than $40-\mathrm{cm}$ thick. The Waiohine loess was deposited following terrace abandonment, rather than synchronous with gravel deposition; therefore, unlike the Porewa and Rata loess units, the age of the Waiohine loess is not commensurate with terrace formation. We obtained four OSL dates that yielded ages from about 5.0 to $10.5 \mathrm{ka}$ (Table 1). These dates correlate to the youngest of Milne's (1973) Ohakean terraces $(\sim 10 \mathrm{ka})$, and we estimate the terrace tread to be abandoned at about 10-12 ka (Table 2). OSL dates of loess at $\sim 13$ to 18 ka correspond to Milne's (1973) oldest terrace $\mathrm{Oh}_{1}$ (Table 2); however, exposures of this terrace were found in only one location: along the low crest of the Harris Ridge Anticline.

\section{Results}

\subsection{Terrace deformation and fold growth}

Terraces deform as passive markers in response to differential rock uplift. Folds and faults transect the Huangarua River and are oriented at both high and low angles to the axis of the valley. Many of these folds are mapped as plunging structures (Fig. 3), some of them are currently active, and the locus of activity (as will be demonstrated below) has shifted among them over time. This differential motion is recorded by the tilt and relative uplift of terraces both perpendicular and parallel to the valley axis (Fig. 9). The former are represented here as "east" and "west" tilts (Fig. 10), whereas the latter are encompassed in the longitudinal terrace and river profiles. The tilting data are analyzed on the basis of "domains" that exhibit generally coherent patterns of deformation (Fig. 11).

\subsection{Tectonic domains}

The tectonic domains are based on direction of tilt, degree of tilt, incision rates, and underlying structure (Figs. 3 and 4). Thirty-five transects oriented perpendicular to the river-valley profile were extracted from the residual surface (Fig. 9). Terrace remnants that were $<30 \mathrm{~m}$ in width (three data points) or that were clearly steepened by hillslope processes by either aggradation or erosion were not included in slope analyses. Slopes were calculated on each transect for each terrace remnant using linear regression techniques and $2 \sigma$ errors. These slopes define terrace tilt perpendicular to the river-valley axis.

\subsection{Longitudinal river profiles}

The long river profile results from a competition among river incision, rock uplift, and lithologic resistance (Sklar and Dietrich, 1998). The modern river traverses three primary lithologic domains (Fig. 12). At the large scales, the river profile appears adjusted to the lithologic resistance of the underlying bedrock: the steepest part of the long profile corresponds with that reach flowing across conglomerate and limestone, whereas the gentler reaches cross sandy mudstone. If we assume that the modern profile has regraded from climatic inputs and is near equilibrium, then depar-

Fig. 11. (A) Shaded relief DEM map of terraces and structure within each tectonic domain (upper left). RS=Rukokoputuna Syncline; BRA=Blue Rock Anticline; HS = Huangarua Syncline; WWA = Wantwood Anticline; WWS = Wantwood Syncline; HS = Huangarua Syncline; $\mathrm{HF}=$ Huangarua fault; and HA= Huangarua Anticline. Tectonic domains (I-VI) are shown in B-F. Domains I to V show a blow-up of each domain and direction of tilt on each terrace (indicated by small arrowhead) in relation to structure. Arrowheads are depicted on each profile for each terrace for which a significant tilt was determined. Arrowheads also vary in size based on scale of the map, not on magnitude of tilt. Numbers indicate transect number. 


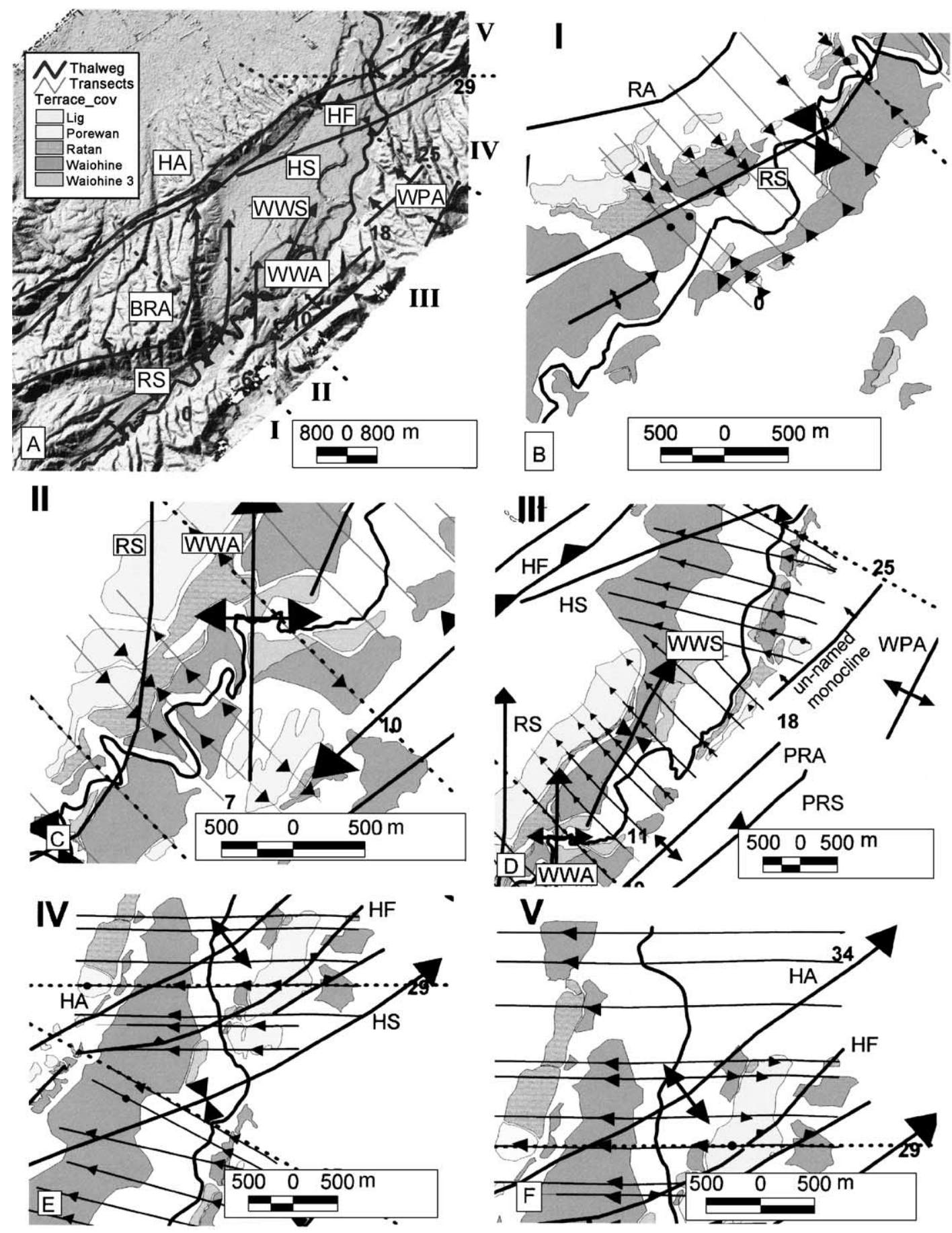




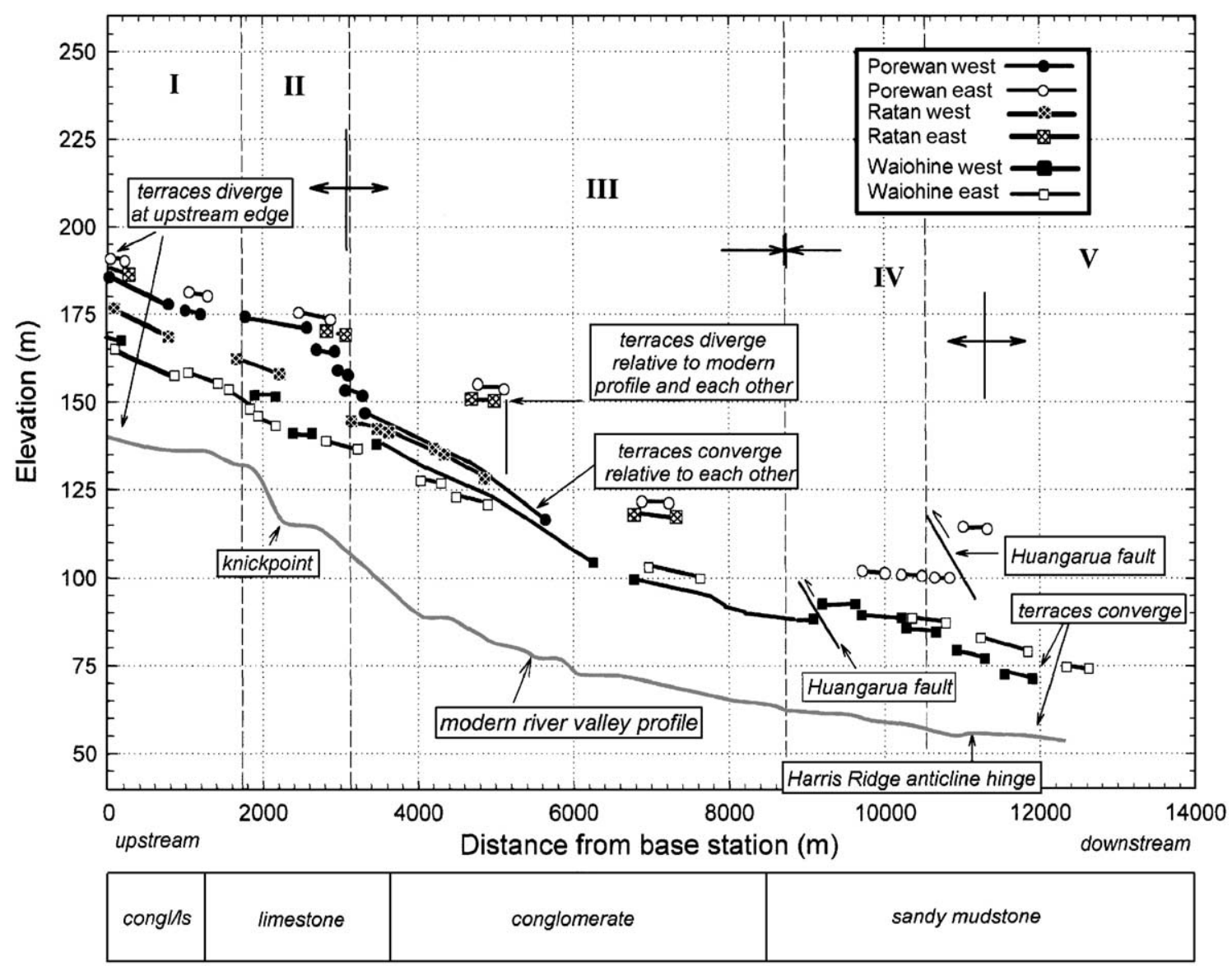

Fig. 12. Longitudinal river valley profile of the Ruakokoputuna-Huangarua River and both east and west side profiles of Porewan, Ratan, and Waiohine terraces. Roman numerals represent tectonic domains (see text for explanation). Areas of terrace profile convergence and divergence are shown on the profile. The Huangarua fault is shown in different locations because the fault crosses the river obliquely. The fault cuts the Waiohine terrace farther upstream relative to the Porewan terrace.

tures from the modern profile, as shown by terraces, should represent tectonic deformation, given that the underlying bedrock has not changed.

\subsection{Upstream reach: tectonic domains I through II}

The most important relationship between terrace deformation and fold growth in the upstream reach is that the direction of tilt of terraces on both sides of the river is consistent with the dip direction of the limbs of Ruakokoputuna Syncline (Figs. 10 and 11). In addition, the dip reversals in Domain II are consistent with the position of the Wantwood Anticline.
Tilting of surfaces of variable age provides information on the growth history of folding. Dips of beds within bedrock (Fig. 4), which is locally $1-2 \mathrm{Ma}$ in age, are often significantly higher than the dips of late Quaternary terrace surfaces, which indicate that folding commenced well before terrace formation. Increase in the tilt of terraces with increasing age (Fig. 13) implies that both the Huangarua Syncline and the Wantwood Anticline continued to grow during the last $\sim 80$ kyears. If, however, folding commenced on the order of 1-2 Ma ago (Lamb and Vella, 1987; Nicol et al., in preparation), then it appears that rates of limb rotation and shortening were generally nonlinear, being higher during the late 


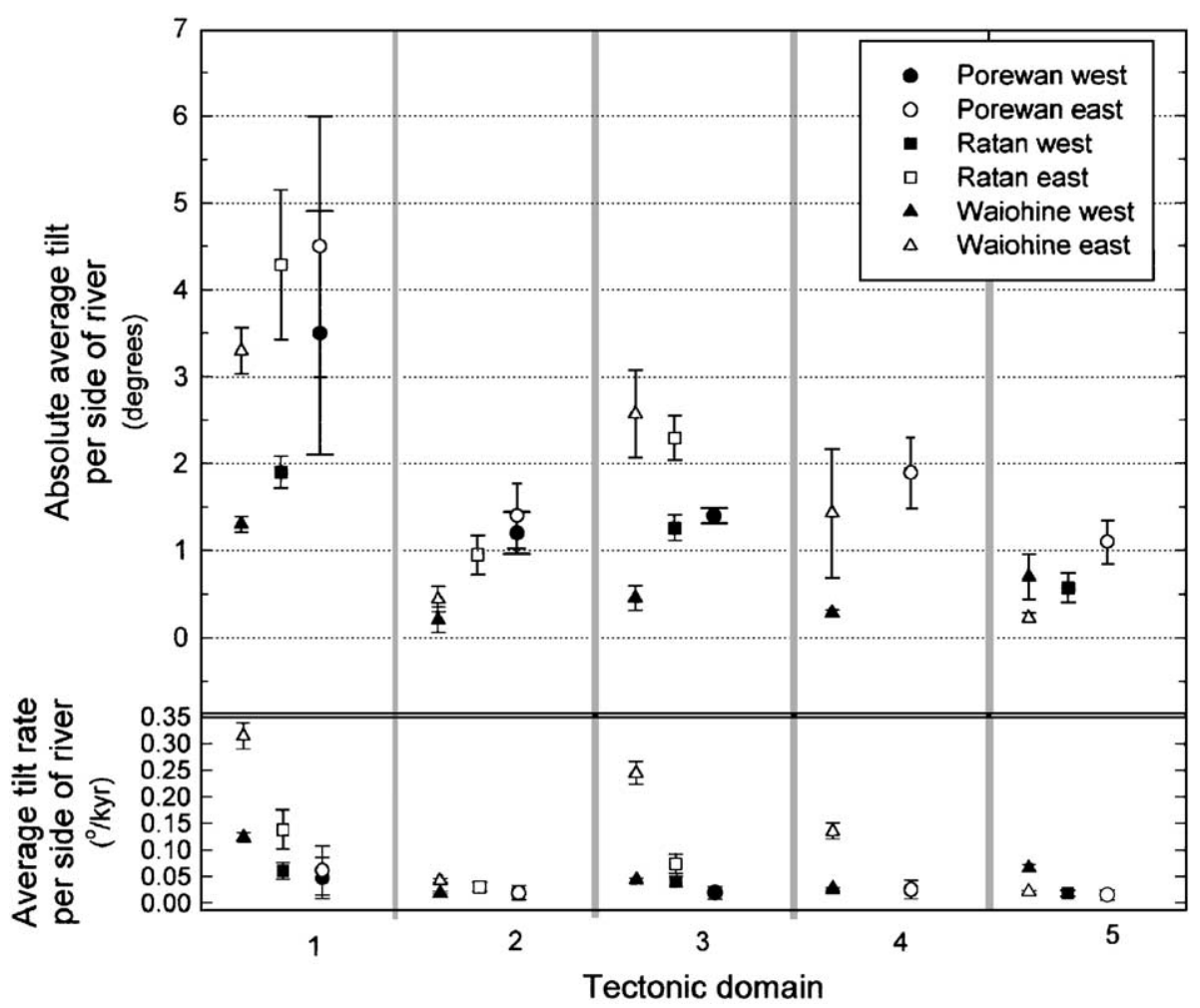

Fig. 13. The top panel indicates the average tilt (degrees) calculated for each tectonic domain and each terrace differentiated by terrace location. The bottom panel shows average tilt rate per domain for terraces on the east vs. west side of the river. These are further differentiated by age of the surface.

Quaternary than prior to terrace formation. In addition, relative rates of tilting on fold limbs need not be maintained as deformation progresses. On the asymmetric Ruakokoputuna Syncline, for example, the relative magnitudes of dip of each limb in bedrock are not mirrored by the terrace data. In particular, steep bedrock dips on the west limb (at $\sim 60^{\circ}$, (Nicol et al., in preparation) have lower dips for each of the three terraces than the east limb, which has only shallow bedrock dips of $\sim 9-12^{\circ}$ (Figs. 4 and 11). These data require that relative rates of tilting on each limb have changed through time with higher rates of tilting on the shallow limb during the last 80 kyears. Terraces may also be recording the growth of new structures. We are unable to differentiate, within the limits of the data, between changing rates on the same structures or growing new structures.

In the upstream reach, longitudinal stream profiles provide inconclusive evidence for active folding (Fig.
12). Segments of terrace longitudinal profiles in Domains I and II are steeper than the modern river profile and result in upstream terrace divergence away from the modern profile (Fig. 12). Tectonic geomorphologists have traditionally construed terrace divergence as an indication of relative bedrock uplift (Keller and Pinter, 1996); however, in this domain, divergence between terraces and the modern river profile may reflect the presence of a bedrock knickpoint in Domain II (Fig. 12).

\subsection{Midstream reach: tectonic domain III}

All of the terraces are dipping toward the west in Domain III. Terrace tilts on the west side of the river reflect folding of the Huangarua Syncline, and terraces on the east side of the river are in response to uplift on the Windy Peak Anticline. The absolute average tilt is greatest for the east side Waiohine 


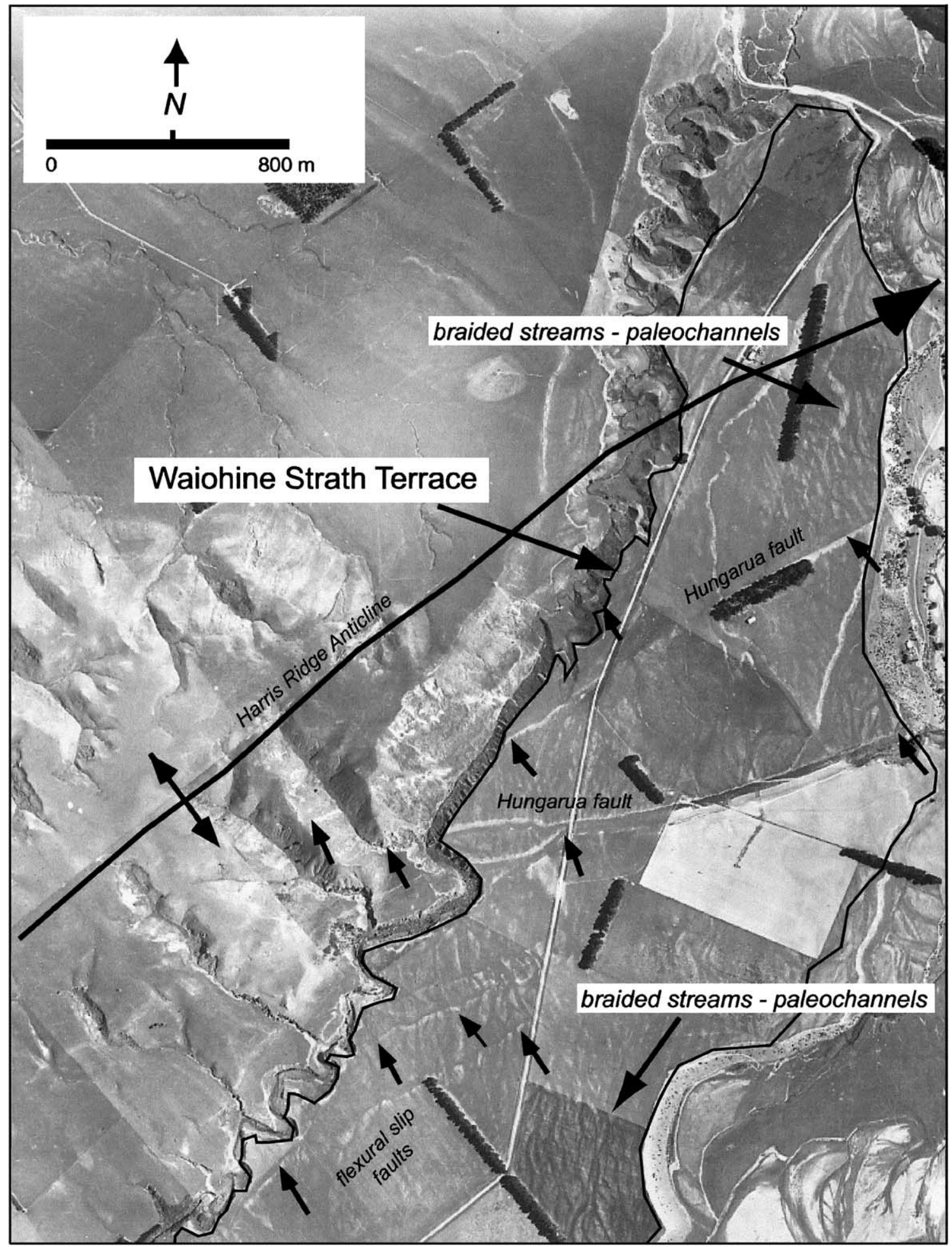


and Ratan terraces at $2.6^{\circ}$ and $2.2^{\circ}$, respectively (Fig. 13). In contrast, Waiohine terrace treads on the west have an average absolute tilt of only $0.45^{\circ}$ (Fig. 13).

Longitudinal profiles of terraces on the west side of the river converge relative to each other and relative to the modern river profile (Fig. 12). Sedimentary infilling of the subsiding hinge of the Huangarua Syncline was more rapid than river incision and contributed to terrace convergence on the west side of the river. Each new terrace tread, from Porewan to Ratan, was graded to a new, rising base level. The terrace sequence converged relative to each other and consequently had little vertical separation (Fig. 12). This is a function of the proximity of the west-side terraces to the hinge of the Huangarua Syncline (Figs. 11 and 12). The downstream convergence of the terraces on the west side coincides almost exactly with the plunging nose of the Wantwood Syncline. In contrast, terrace profiles on the east side of the river flatten out or diverge from the modern river profile where these terraces are more affected by uplift along the NW limb of the Windy Peak Anticline (Figs. 3, 11, and 12).

As with the upper reach, bedrock dips are significantly higher than the dips of late Quaternary terrace surfaces (Fig. 4). This is consistent with the age of growth strata imaged in a seismic reflection line, which indicate that folding of Huangarua Syncline commenced $\sim 1.8 \mathrm{Ma}$ ago (Nicol et al., in preparation). Increase in tilt of terraces with increasing age also suggests that Huangarua Syncline and Windy Peak Anticline have accommodated progressive shortening in the last $\sim 80$ kyears. In common with folds further upstream, rates of tilting during the late Quaternary (Fig. 13) were approximately twofold higher in the Holocene (west of the river $\sim 0.4 \pm 0.15^{\circ} / 10$ kyears) than for the interval post $80 \mathrm{ka}$ (west of the river $\sim 0.23 \pm 0.04^{\circ} / 10$ kyears).

\subsection{Downstream reach: tectonic domains $I V$ and $V$}

Close correlations between the location of folds in bedrock and tilt directions of terraces that are present in the upper reach are less apparent in Domains IV and V. Locally, the best data for showing the coincidence of fold hinges occur across Harris Ridge Anticline within Domain V (Fig. 11). Huangarua Syncline, which crosses this reach of the river obliquely, is not reflected in the pattern of tilting of the terraces, which dip to the west on both limbs of the fold. These data indicate that, in Domain V, Harris Ridge Anticline increased in amplitude since formation of the Waiohine terrace, which is consistent with the presence of extensional faults in the crest of the fold and offset of the terrace by the Huangarua fault. In contrast, the Huangarua Syncline has not been steadily growing during the last $10-13 \mathrm{ka}$. Instead, the Waiohine terrace on the western limb of the syncline is offset by three faults that are shown on Fig. 14. These faults are inferred to be flexural-slip faults, upthrown on the SE and similar in geometry to faults in the north bank of the Huangarua River (Lamb and Vella, 1987; Nicol and Van Dissen, 1997; Nicol et al., in preparation). The flexural slip faults contribute to the general NW tilt direction on the terrace (Figs. 3 and 11); therefore, the apparent absence of eastward tilting on the western limb of this syncline may in part reflect the mode of deformation rather than indicating an absence of strain within the limb.

The Huangarua fault is an active reverse fault, which also cuts across Domains IV and V (Fig. 11). The fault offsets Porewan and Waiohine terraces with throws of $40 \mathrm{~m}$ (Vella et al., 1988) and $5 \mathrm{~m}$, respectively (Fig. 12) and vertical displacement rates of $\sim 0.5 \mathrm{~mm} /$ year during the late Quaternary (Nicol et al., in preparation). The topographic scarp has been degraded and only shows $\sim 15-20 \mathrm{~m}$ of offset. Vertical displacement rates are based on stratigraphic and tephra control encountered in auger holes (Vella et al., 1988). Faulting and folding have resulted in steepening of the Waiohine surface relative to the modern river profile downstream of the fault (Fig. 12).

\section{Discussion}

\subsection{Benefits and limitations of using DEM for active folding}

Fluvial terraces are ubiquitous in the valleys of New Zealand. Such terraces provide valuable geo-

Fig. 14. A graphic representation of an aerial photograph. The most extensive strath terrace, Waiohine, is shown. Arrows point to the endpoints of flexural slip faults and the Huangarua fault. Note paleostream morphology on the terrace tread exhibits a braided pattern. 
morphic markers that can be used to track deformation associated with active faults and growing folds. In order to define rates of tectonism, the age of a terrace and its displacement from its depositional geometry must be determined. In this study, we have developed new data sets (OSL ages of loess on terraces and topographic anomalies derived from TOPSAR digital topography) that permit us to define spatial and temporal variations in tectonism in the Wairarapa Valley.

We have generated 16 new OSL dates on loess mantling strath surfaces that are in agreement with several regional and local studies (Vella, 1963; Cowie, 1964; Leamy et al., 1973; Cowie and Milne, 1973; Milne, 1973; Milne and Smalley, 1979; Kaewyana, 1980; Palmer, 1982; Parfitt et al., 1983, 1984; Vella et al., 1988; Alloway, 1989; Palmer and Vucetich, 1989; Warnes, 1989; Grapes, 1991; Alloway et al., 1992; Palmer and Pillans, 1996; Vucetich et al., 1996; Shulmeister, 1999). Given the analytical uncertainties, all of the ages are in correct stratigraphic order. Our correlations among the studied sections (Fig. 8) indicate that two to six dates have been obtained for each interval of loess deposition. The quality of age assignments of each loess unit reflects the number of ages for it. With only two dates, the Porewa loess is only loosely constrained to include an interval around 75$70 \mathrm{ka}$ and could extend considerably younger or older. In contrast, with 6 dates, the Ohakea loess is effectively defined as spanning at least 12 kyears (26-14 ka) and could range from 30 to $11 \mathrm{ka}$. Similarly, the Rata loess spans at least from 42 to $31 \mathrm{ka}$, and the weak soil capping the Rata loess must have been formed between 31 and $26 \mathrm{ka}$.

The current study provides insights into the benefits and limitations of using high-resolution DEMs to analyze deformation of alluvial surfaces. Perhaps the key insight is that subtle folding may be detected using this methodology even where tec-tonic tilting cannot be confidently identified in the field or from longitudinal terrace profiles. Tilt rates of $<1^{\circ} / 10$ kyears are readily identified in the DEM analysis, such that progressive tilting and changes in rates through time can be documented. Detailed mapping of folds in bedrock has allowed us to identify tilted terrace geometries that are consistent with known bedrock structure, and therefore, terrace geometries can be related to tectonic tilting. The absence of bedrock data would ultimately make the task of recognizing tectonically tilted terraces more difficult.

Terraces that are preserved across (along transverse drainages) growing folds can be used as strain markers that provide a better three-dimensional pattern of displacement. Across the crest of the larger folds in the study area (much of the Harris Ridge and Windy Peak anticlines, for example), we lack this type of preservation, such that it becomes more difficult to use longitudinal profiles to constrain predictable fold model theory.

Given these caveats, the following discussions illustrate the Huangarua River's response to active fold growth. Paleosol and loess stratigraphy that overlie the terraces are used as proxies for climate change and up-basin sediment fluxes. Extensive strain data, in the form of geomorphic markers such as terrace surfaces, are used to reconstruct the kinematic evolution of Wairarapa folds.

\subsection{Implications of data for fold growth}

Deformed late Quaternary terrace surfaces in the Huangarua River valley provide evidence for actively growing folds. Geologic mapping, combined with subsurface data, indicate that fold hinges are fixed in space throughout the growth of the folds (to within 100-m horizontal resolution. Thus, fold models requiring migrating hinges (Suppe and Medwedeff, 1990; Suppe et al., 1992; Hardy and Poblet, 1994; Ford et al., 1997) are not consistent with these data. Rather, strain is being taken up in tightening fold hinges.

There is also evidence to suggest that in the Huangarua River valley faulting and folding are taking place contemporaneously at the ground surface for at least the last 40 kyears (Nicol and Van Dissen, 1997; Nicol et al., in preparation). Whether this is also the case over the last 1-2 Myears is uncertain. The data shows that prior to $2 \mathrm{Ma}$, there can have been no more than a few hundred meters of sedimentary rocks overlying the Huangarua fault (Nicol et al., in preparation); therefore, the fault tip did not have far to propagate to reach the surface once deformation resumed at about $2 \mathrm{Ma}$.

Observed tilting of terraces suggests that rates of deformation during the Holocene are approximately 
two-fold higher than rates between 10 and $80 \mathrm{ka}$ for at least the last 40 kyears. Whether this is also the case over the last 1-2 Myears is uncertain. The data shows that prior to $2 \mathrm{Ma}$, there can have been no more than a few hundred meters of sedimentary rocks overlying the Huangarua fault (Nicol et al., in preparation); therefore, the fault tip did not have far to propagate to reach the free surface once deformation resumed at about 2 Ma.

Observed tilting of terraces suggests that rates of deformation during the Holocene are approximately two-fold higher than rates between 10 and $80 \mathrm{ka}$ (Fig. 13). Beanland (1995) identified a similar rate change for fault slip rates in the North Island and suggested that this might be a sampling artifact (i.e., we have fortuitously sampled an interval of clustered deformation characterized by high strain rates).

The spatial patterns of terrace tilts in relation to the underlying bedrock show that the locus of fold growth has shifted throughout the Huangarua. Increase in the tilt of terraces with increasing age (Fig. 13) implies that both the Huangarua Syncline and the Wantwood Anticline continued to grow during the last $\sim 80$ kyears, while the Ruakokoputuna Syncline, the Blue Rock Anticline, and the Point Range Anticline/Syncline pair are inactive or at least less active relative to other dominant structures (Fig. $3)$. In addition, the relative rates of tilting on fold

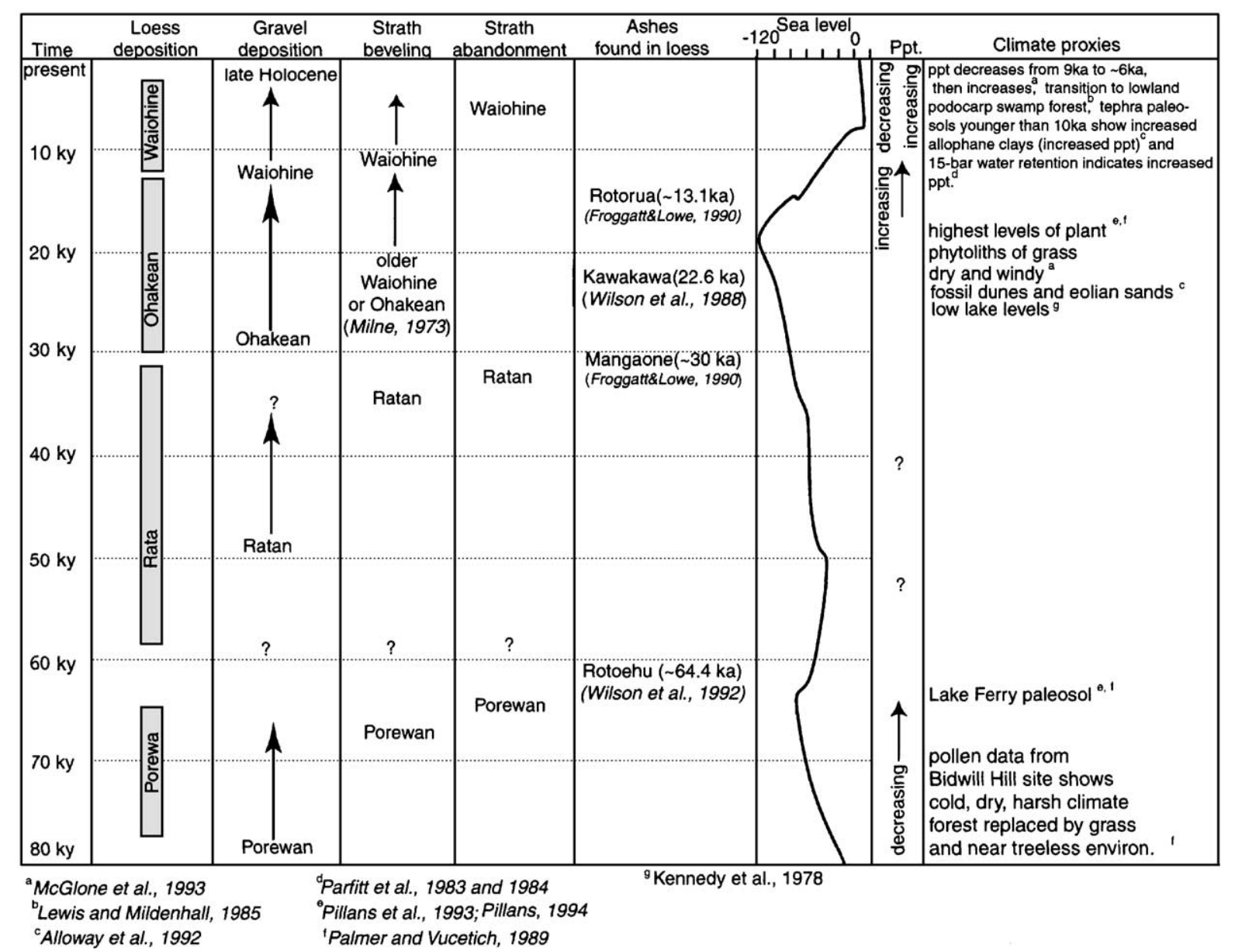

Fig. 15. Geomorphic relationships between gravel deposition, strath incision, and base level in relation to climate proxies. Letters correspond to the references cited. Note that strath cutting is contemporaneous with periods of increased sediment supply and strath abandonment is during periods of increased precipitation (Kennedy et al., 1978; Froggatt and Lowe, 1990; Wilson et al., 1992; Pillans, 1994). 
limbs need not be maintained as deformation progresses. Terraces on the west side of the river converge relative to each other and relative to the modern river profile (Fig. 12). Sedimentary infilling of the subsiding hinge of the Huangarua Syncline contributed to terrace convergence on the west side of the river. In contrast, terrace profiles on the east side of the river flatten out or diverge from the modern river profile where these terraces are more affected by uplift along the NW limb of the Windy Peak Anticline (Figs. 4, 11, and 12).
Locally, the best data for showing the coincidence of fold hinges occurs across Harris Ridge Anticline within Domain V (Fig. 11). These data indicate that in Domain V Harris Ridge Anticline increased in amplitude since formation of the Waiohine terrace, which is consistent with the presence of active, extensional faults in the crest of the fold and offset of the terrace by the Huangarua fault. The use of residual surface maps is useful in pinpointing both maximum deformation and tilt directions. Outcrop data is important when using residual maps because discrete structural

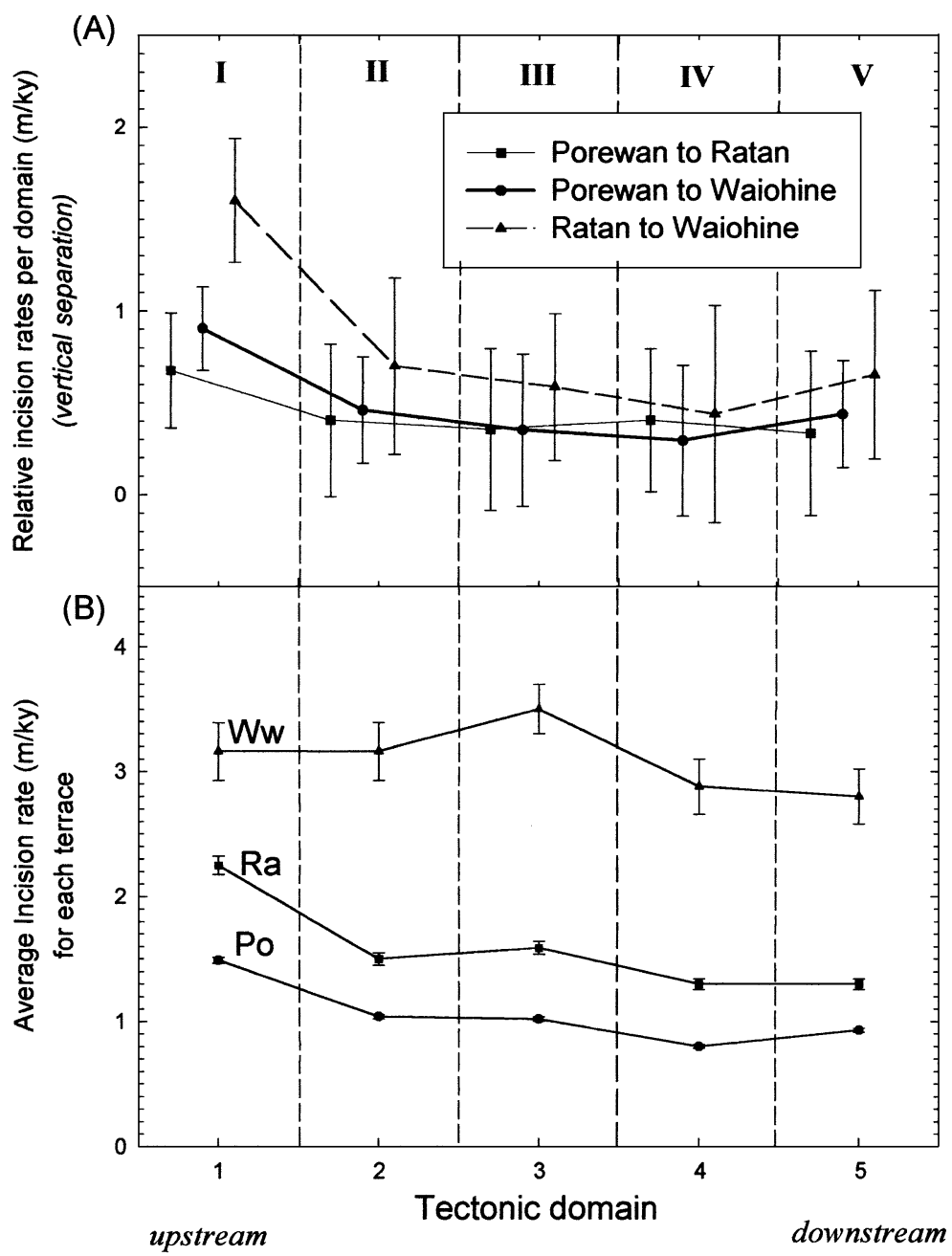

Fig. 16. (A) Relative incision rates (vertical separation/per time interval) calculated for each tectonic domain. Error analysis is discussed in detail in the text. However, it is important to note that the errors are compounded for both terraces in the relative incision rates. (B) Average incision rates $(\mathrm{m} /$ kyear) calculated for each tectonic domain. Calculated errors in this analysis reflect the height above base level and the OSL age assigned to the terrace. 
displacements, such as slip on flexural slip faults observed only in cross section, can contribute to terrace tilts (Figs. 3 and 11).

\subsection{Terrace genesis in the Huangarua River valley}

Terrace genesis in the Huangarua River valley is dominated by creation and abandonment of strath terraces (Fig. 15). Terrace formation and preservation may be influenced by tectonic and climatic factors (Vella et al., 1988; Bull, 1991). Here, the roles of both local base level and sediment supply are explored in relation to terrace formation and the rate of tectonic and climatically induced processes in the Huangarua River.

Uplift rates of $0.5-1.0 \mathrm{~m} / \mathrm{ka}$ in the region of Huangarua valley over the last 125 kyears (Ghani, 1978; Pillans et al., 1993; Beanland, 1995) are comparable to rates of incision, and almost certainly that over intervals of $10-50$ kyears uplift has influenced the pattern of long-term river incision (Figs. 13, 16, and 17). However, given the fact that the terraces show a progressive tilting (Fig. 13) that is relatively uniform, the striking increase in vertical incision rates (Figs. 16 and 17) in the last 13 kyears correlates with punctuated intervals (14-9 and 6-3 ka) of increased precipitation (McGlone et al., 1993) where discharge is greater than sediment load (Fig. 15).

Using our OSL dates, soil stratigraphy, and relevant climate proxy data as points of departure, we envision that toward the end of cool periods hillslopes are sparsely vegetated and consequently have low infiltration. During the initial stages of deglaciation, as precipitation increases, high runoff on hillslopes causes both discharge and the hillslope sediment flux to increase. Increased sediment loads and periods of relatively stable, or even rising, local base level cause river behavior to change to that of channel widening and braiding. An aerial photograph (1:6000) of the most ubiquitous and youngest strath terrace (Waiohine) shows braided stream morphology preserved by loess that has in-filled paleochannels (Fig. 14).

We hypothesize that terrace formation in the Wairarapa Valley is driven primarily by climatic fluctuations rather than by variations in tectonic rates. Tectonically driven uplift provides a steady forcing

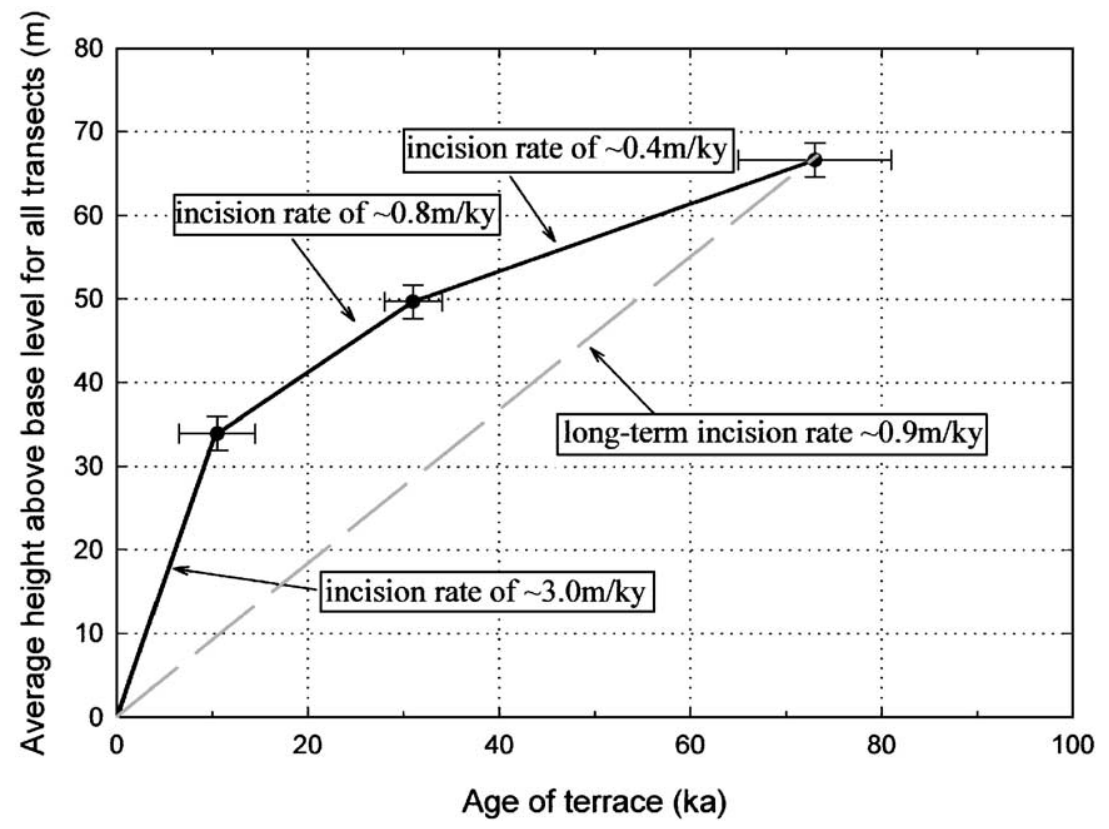

Fig. 17. Incision rates are calculated based on terrace tread height above local base level. Rates are calculated for all transects for each terrace versus the age of the terrace. Note that the age range for the Waiohine terrace extends to $\sim 14 \mathrm{ka}$. This would reduce the incision rate to $\sim 2.4 \mathrm{~m} /$ kyears. 
function, which causes an overall incision of the Huangarua River over the past 125 kyears (Nicol et al., in preparation). Higher frequency, climatically modulated variations in sediment flux and river discharge (Bull, 1991) are superimposed on this tectonic signal and exert the dominant control on the creation and preservation of terraces. When the sediment entering the river system exceeds the transport capacity, the river aggrades. We argue that such aggradation tends to happen during times of rapid environmental change, such as occurs at the transitions from stadial to interstadial intervals.

In the absence of more extensive temporal control, this model can not be verified. When compared with the global oxygen isotope record, the chronology of loess deposition indicates loess was accumulated primarily during stadial intervals. Straths were cut prior to the inception of the next interval of loess accumulation and are, therefore, either restricted to interstadial or transitional (stadial/interstadial) intervals. Data from previous studies has shown that river sediment fluxes have significantly increased during these transitional climatic intervals. For example, near the termination of the MIS 2 glaciation, many of the lowland surfaces adjacent to the Axial Ranges were buried by large alluvial fans, as drainage basins were inundated by an enhanced sediment flux (Milne, 1973; Palmer and Vucetich, 1989). This period of time has been characterized as one of great environmental disturbance and increased sediment supply from hillslopes (Palmer and Vucetich, 1989). Our data show that the Waiohine strath surfaces were cut prior to $10 \mathrm{ka}$ and probably were created near the end of the enhanced sediment flux. We infer that the older strath terraces resulted from analogous intervals of aggradation, equilibrium, and incision.

\section{Conclusions}

Analysis of high-resolution DEM data serves to quantify river response and subtle rates of folding in an active fold-and-thrust belt in North Island, New Zealand. Elevation data from deformed fluvial terraces constrain progressive fold growth. Based on regionally extensive strath terraces, three-dimensional topographic anomalies are defined as departures from a hypothetical strath surface parallel to the modern valley profile. These anomalies define progressive warping of these geomorphic markers during folding. Optically stimulated luminescence dating of the loess and paleosol sequences overlying the straths permits terrace correlation within the study area and defines rates of deformation and incision over the past 80 kyears. By utilizing deformed surfaces rather than individual topographic profiles, subtle folding can be defined. Comparisons of these surface folds with the underlying structural geometry indicates that folds have deformed through limb tightening with little hinge migration over the past 2 Myears.

The nature and variability of fold growth on individual structures throughout the southern Wairarapa valley does not control terrace genesis or the preservation of gravel. Instead, cutting of straths appears linked to times of climatic transition from stadial to interstadial conditions. However, in the Huangarua River valley, fold growth or base level lowering is not the controlling factor in terrace genesis. In contrast to traditional interpretations of strath terrace formation, straths are beveled during periods of increased sediment influx. We hypothesize that, following initial aggradation due to enhanced sediment supply, straths are beveled laterally during brief intervals when the sediment supply and transport capacity are in near balance. Limited data on the timing of strath creation and changes in Late Glacial sediment supply in New Zealand are consistent with this model, but more evaluation is needed. Overall, the succession of strath terraces in the Wairarapa result from the superimposition of high frequency, climatically modulated changes on sustained patterns of tectonic deformation. Data from climate proxies and OSL dates support the conclusion that terrace formation in the Wairarapa valley is driven by sediment influxes that are much more rapid and of greater magnitude than rates of deformation.

\section{Acknowledgements}

This research was supported by NSF grant EAR 97-06294. We would like to thank NASA-JPL for the TOPSAR digital elevation data. We extend thanks both to Dr. Rudy Slingerland and Dr. Kevin Furlong at Penn State University for provocative discussions and to the scientific community of Victoria University, 
Wellington, and the Institute of Geological and Nuclear Sciences (IGNS) for their generosity both personally and professionally.

\section{References}

Alloway, B.V., 1989. The late Quaternary cover bed stratigraphy and tephrochronology of north-eastern and central Taranaki, New Zealand. PhD Thesis, Massey University, Palmerston North, New Zealand.

Alloway, B.V., Stewart, R.B., Neall, V.E., Vucetich, C.G., 1992. Climate of the last glaciation in New Zealand, based on aerosolic quartz influx in an andesitic terrain. Quaternary Research $38,170-179$.

Ballance, P.F., 1976. Evolution of the Upper Cenozoic magmatic arc and plate boundary in northern New Zealand. Earth and Planetary Science Letters 28, 356-370.

Beanland, S., 1995. The North Island Dextral Fault Belt, Hikurangi Subduction Margin, New Zealand, PhD Dissertation, Victoria University of Wellington, New Zealand.

Bull, W.B., 1991. Geomorphic Responses to Climate Change. Oxford Univ. Press, Oxford, UK.

Burbank, D.W., Meigs, A., Brozovic, N., 1996. Interactions of growing folds and coeval depositional systems. Basin Research 8, 199-223.

Burnett, A.W., Schumm, S.A., 1983. Alluvial-river response to neotectonic deformation in Louisiana and Mississippi. Science 222 (4169), 49-50.

Collen, J.D., Vella, P., 1984. Hautotara, Te Muna and Ahiaruhe Formations, middle to late Pleistocene, Wairarapa, New Zealand. Journal of the Royal Society of New Zealand 14, 296-317.

Cowie, J.D., 1964. Loess in the Manawatu district, New Zealand. New Zealand Journal of Geology and Geophysics 7, 389-396.

Cowie, J.D., Milne, D.G., 1973. Maps and sections showing the distribution and stratigraphy of North Island Loess and associated deposits, New Zealand. New Zealand Soil Survey Report, vol. 6. DSIR Soil Bureau, Lower Hutt, New Zealand.

De Angelis, M., Barkov, N.I., Petrov, V.N., 1987. Aerosol concentrations over the last climatic cycle (160 kyr) from an Antarctic ice core. Nature 325, 318-321.

De Mets, C., Gordon, G.G., Argus, D.F., Stein, S., 1994. Effect of recent revisions to the geomagnetic reversal time scale on estimates of current plate motions. Geophysical Research Letters 21 (20), 2192-2194.

Ford, M., Williams, E.A., Artoni, A., Verges, J., Hardy, S., 1997. Progressive evolution of a fault-related fold pair from growth strata geometries, Sant Llorenc de Morunys, SE Pyrenees. Journal of Structural Geology 19, 413-441.

Froggatt, P.C., Lowe, D.J., 1990. A review of late Quaternary silicic and some other tephra formations from New Zealand: their stratigraphy, nomenclature, distribution, volume, and age. New Zealand Journal of Geology and Geophysics 33, 89-109.

Ghani, M.A., 1978. Late Cenozoic vertical crustal movements in the central part of New Zealand. New Zealand Journal of Geology and Geophysics 21, 117-125.
Grapes, R.H., 1991. Aggradation surfaces and implications for displacement rates along the Wairarapa Fault, southern North Island, New Zealand. Catena 18, 453-469.

Hardy, S., Poblet, J., 1994. Geometric and numerical model of progressive limb rotation in detachment folds. Geology 22, $371-374$.

Kaewyana, W., 1980. Late Quaternary alluvial terraces and their cover bed stratigraphy, Eketahuna and Pahiatua districts, New Zealand. MS Thesis, Victoria University of Wellington, New Zealand.

Keller, E.A., Pinter, N., 1996. Active Tectonics, Earthquakes, Uplift and Landscapes. Prentice Hall, Upper Saddle River, NJ, 337 pp.

Keller, E.A., Rockwell, T.K., Clark, M.N., Dembroff, G.R., Johnson, D.L., 1982. Tectonic geomorphology of Ventura, Ojai and Santa Paula areas, western Transverse Ranges, California. In: Cooper, J.D. (Ed.), Neotectonics in Southern California: Geologic Society of America Cordilleran Section Field Guidebook, pp. $25-42$.

Kennedy, N.M., Pullar, W.A., Pain, C.F., 1978. Late Quaternary land surfaces and geomorphic changes in the Rotorua Basin. New Zealand Journal of Science 21, 249-264.

Lamb, S.H., Vella, P., 1987. The last million years of deformation in part of the New Zealand plate-boundary zone. Journal of Structural Geology 9, 877-891.

Lavé, J., Avouac, J.P., 2000. Active folding of fluvial terraces across the Siwaliks Hills, Himalayas of central Nepal. Journal of Geophysical Research 105 (B3), 5735-5770.

Leamy, M.L., Milne, J.D.G., Pullar, W.A., Bruce, J.G., 1973. Paleopedology and soil stratigraphy in the New Zealand Quaternary Succession. New Zealand Journal of Geology and Geophysics $16,723-744$.

Lewis, K.B., Mildenhall, D.C., 1985. The late Quaternary seismic, sedimentary, and palynological stratigraphy beneath Evans Bay, Wellington Harbour. New Zealand Journal of Geology and Geophysics $28,129-152$.

Marden, M., Neall, V.E., 1990. Dated Ohakean terraces offset by the Wellington Fault, near Woodville, New Zealand. New Zealand Journal of Geology and Geophysics 33, 449-453.

McGlone, M.S., Salinger, M.J., Moar, N.T., 1993. Paleovegetation studies of New Zealand's climate since the last glacial maximum. In: Wright Jr., H.E., Kutzbach, T., Webb III, T., Ruddiman, W.F., Street-Perrott, F.A., Bartlein, P.J. (Eds.), Global Climates Since the Last Glacial Maximum. University of Minnesota Press, St. Paul, MN, pp. 294-317.

Merritts, D.J., Vincent, K.R., Wohl, E.E., 1994. Long river profiles, tectonism, and eustasy: a guide to interpreting fluvial terraces. Journal of Geophysical Research 99 (B7), 14031-14050.

Milne, J.D., 1973. Upper Quaternary geology of the Rangitikei drainage basin. PhD Dissertation, Victoria University of Wellington, New Zealand.

Milne, J.D.G., Smalley, I.J., 1979. Loess deposits in the southern part of the North Island of New Zealand: an outline stratigraphy. Acta Geologica Academiae Scientiarum Hungaricae 22, $197-$ 204.

Molnar, P., Brown, E.T., Burchfiel, B.C., Deng, Q., Feng, X., Li, J., Raisbeck, G.M., Shi, J., Wu, Z., Yiou, F., You, H., 1994. Quaternary climate change and the formation of river terraces across 
growing anticlines on the north flank of the Tien Shan, China. Journal of Geology 102, 583-602.

Nelson, C.S., Hendy, C.H., Jarrett, G.R., Cuthbertson, A.M., 1985. Near-synchroneity of New Zealand alpine glaciations and Northern Hemisphere continental glaciations during the past 750 kyr. Nature 318, 361-363.

Nicol, A., Van Dissen, R., 1997. A reassessment of abruptly fanning bed dips on the northwest limb of the Huangarua Syncline, Wairarapa, New Zealand. New Zealand Journal of Geology and Geophysics (40), 257-260.

Nicol, A., Alloway, B., Tonkin, P., 1994. Rates of deformation, uplift and landscape development associated with active folding in Waipara area of North Canterbury, New Zealand. Tectonics $13,1327-1344$.

Nicol, A., Van Dissen, R., Vella, P., Alloway, B., Melhuish, A., in preparation. Growth of contractional structures during the last $10 \mathrm{Ma}$ at the southern end of the emergent Hikurangi forearc, New Zealand. Tectonics.

Palmer, A.S., 1982. The stratigraphy and selected properties of loess in Wairarapa, New Zealand. PhD Dissertation, Victoria University of Wellington, New Zealand.

Palmer, A.S., Pillans, B.J., 1996. Record of climatic fluctuations from ca. 500 ka loess deposits and paleosols near Wanganui, New Zealand. Quaternary International 34-36, 155-162.

Palmer, B.A., Vucetich, C.G., 1989. Last glacial loess and early last glacial vegetation history of Wairarapa Valley, New Zealand. New Zealand Journal of Geology and Geophysics 32, 499-513.

Parfitt, R.L., Russell, M., Orbell, G.E., 1983. Weathering sequence of soils from volcanic ash involving allophane and halloysite, New Zealand. Geoderma 29, 41-57.

Parfitt, R.L., Saigusa, M., Eden, D.N., 1984. Soil development processes in an Aqualf-Ochrept sequence from loess with admixtures of tephra, New Zealand. New Zealand Journal of Soil Science 35, 625-640.

Pazzaglia, F.J., Gardner, T.W., 1993. Fluvial terraces of the lower Susquehanna River. Geomorphology 8, 83-113.

Personius, S.F., 1995. Late Quaternary stream incision and uplift in the forearc of the Cascadia subduction zone, western Oregon. Journal of Geophysical Research 100, 20193-20210.

Personius, S.F., Kelsey, H.M., Grabau, P.C., 1993. Evidence for Regional Stream Aggradation in the Central Oregon Coast Range during the Pleistocene-Holocene Transition. Quaternary Research 40, 297-308.

Pillans, B., 1994. Direct marine-terrestrial correlations, Wanganui Basin, New Zealand: the last 1 million years. Quaternary Science Reviews 13, 189-200.

Pillans, B., McGlone, M., Palmer, A., Mildenhall, D., Alloway, B., Berger, G., 1993. The last glacial maximum in central and southern North Island, New Zealand: a paleoenvironmental reconstruction using Kawakawa Tephra Formation as a chronostratigraphic marker. Palaeogeography, Palaeoclimatology, Palaeoecology 101, 283-304.
Prescott, J.R., Hutton, J.T., 1995. Environmental dose rates and radioactive disequilibrium from some Australian luminescence dating sites. Quaternary Science Reviews 14 (no. 4), 439-448.

Rockwell, T., Keller, E.A., Clark, M.N., Johnson, D.L., 1984. Chronology and rates of faulting of Ventura River terraces, California. Geological Society of America Bulletin 95, 1466-1474.

Shulmeister, J., 1999. Australasian evidence for mid-Holocene climate change implies precessional control of Walker Circulation in the Pacific. Quaternary International 57/58, 81-91.

Sklar, L., Dietrich, W.E., 1998. River longitudinal profiles and bedrock incision models: stream power and the influence of sediment supply. In: Tinkler, K.J., Wohl, E.E. (Eds.), Rivers Over Rock: Fluvial Processes in Bedrock Channels. American Geophysical Union, Washington, DC, pp. 237-260.

Stewart, R.B., Neall, V.E., 1984. Chronology of paleoclimatic change at the end of the last glaciation. Nature 311, 47-48.

Suppe, J., Medwedeff, D.A., 1990. Geometry and kinematics of fault-propagation folding. Eclogae Geologicae Helveticae, 83.

Suppe, J., Chou, G.T., Hook, S.C., 1992. Rates of folding and faulting determined from growth strata. In: McClay, K.R. (Ed.), Thrust Tectonics. Chapman \& Hall, London, pp. 105-121.

Theide, J., 1979. Wind regimes over the late Quaternary southwest Pacific Ocean. Geology 7, 259-262.

Vella, P., 1963. Upper Pleistocene succession in the inland part of Wairarapa Valley, New Zealand. Transactions of the Royal Society of New Zealand, Geology 2, 63-78.

Vella, P., Briggs, W.M., 1971. Lithostratigraphic names, Upper Miocene to Lower Pleistocene, northern Aorangi Range, Wairarapa. New Zealand Journal of Geology and Geophysics 14, 253-274.

Vella, P., Worakoon, D., Vucetich, C.G., 1988. Late Quaternary terraces and their cover beds, north-western Wairarapa, New Zealand, and provisional correlations with oxygen isotope stages. Journal of the Royal Society of New Zealand 18, 309-324.

Vucetich, C.G., Vella, P., Warnes, P.N., 1996. Antepenultimate glacial to last glacial deposits in southern Wairarapa, New Zealand. Journal of the Royal Society of New Zealand 26, 469-482.

Walcott, R.I., 1987. Reconstructions of the New Zealand region for the Neogene. Palaeogeography, Palaeoclimatology, Palaeoecology 46, 217-231.

Warnes, P.N., 1989. The Quaternary geology of the area east of Carterton, Wairarapa, New Zealand. MS Thesis, Victoria University of Wellington, New Zealand.

Wilson, C.J.N., Switsur, V.R., Ward, A.P., 1988. A new C14 age for the Oruanui (Wairakei) eruption, New Zealand. Geological Magazine 125, 297-300.

Wilson, C.J.N., Houghton, B.F., Lanphere, M.A., Weaver, S.D., 1992. A new radiometric age estimate for the Rotoehu Ash from Mayor Island Volcano, New Zealand. New Zealand Journal of Geology and Geophysics 35, 371-374. 